\title{
Space time evolution of the trophic state of a subtropical lagoon: Lagoa da Conceição, Florianópolis Island of Santa Catarina, Brazil
}

\section{Evolução espaço temporal do estado trófico de uma laguna subtropical: Lagoa da Conceição, Ilha de Santa Catarina, Brasil}

\author{
Victor Eduardo Cury Silva ${ }^{1}$, Davide Franco ${ }^{1}$, Alessandra Larissa Fonseca ${ }^{1}$, Maria Luiza Fontes ${ }^{1}$ \\ and Alejandro Rodolfo Donnangelo ${ }^{1}$ \\ ${ }^{1}$ Universidade Federal de Santa Catarina, Florianópolis, SC, Brazil \\ E-mails: victoreduardo@hotmail.com, vitaumedu@gmail.com (VECS),d.franco.maare@gmail.com (DF), alarissa.fonseca@gmail.com (ALF), \\ fontesml@ccb.ufsc.br (MLF), alejandro.varela@posgrad.ufsc.br (ARD)
}

Received: February 15, 2016 - Revised: July 11, 2016 - Accepted: September 15, 2016

\begin{abstract}
High levels of eutrophication in coastal lagoons due to human activity have been documented worldwide. Among the main impacts observed are anoxia, hypoxia, toxic algal blooms, fish kills, loss of biodiversity and loss of bathing. This study aimed to evaluate the evolution of the trophic state of Lagoa da Conceição, a subtropical lagoon located in an urbanized watershed on the island of Santa Catarina - Brazil. Spatio temporal patterns of stratification and eutrophication were investigated to understand the main biochemical changes over time. The water quality data were obtained from field campaigns supplemented with literature of the last 15 years. The vertical structure of the water column and the trophic state were evaluated by the stratification index and the TRIX index, respectively. Analyses of variance were performed in order to identify possible temporal variations in vertical stratification and trophic level. Eutrophication effects on biogeochemical cycles were verified through a multi-dimensional cluster analysis (MDS) and correlations between variables related to physical, chemical and biological processes were verified by principal component analysis (PCA). The results showed that the water column is homogeneous in all regions except in the central region of the lagoon, and the highest ammonia concentrations and lowest dissolved oxygen concentrations with periods of anoxia are observed in bottom waters. The study looked at the high trophic level of the lagoon and its inability to process the biogeochemical changes imposed by urban development.
\end{abstract}

Keywords: TRIX; Coastal lagoons; Stratification; Hypoxia; Biogeochemical cycles.

\section{RESUMO}

Níveis elevados de eutrofização em lagunas costeiras devido à atividade antrópica têm sido documentados no mundo inteiro. Dentre os impactos observados pode-se destacar anoxia, hipoxia, floração de algas tóxicas, mortalidade de peixes, redução da biodiversidade e perda da balneabilidade. O presente estudo teve por objetivo avaliar a evolução do estado trófico da Lagoa da Conceição, uma laguna subtropical localizada em uma bacia hidrográfica urbanizada na Ilha de Santa Catarina - Brasil. Para compreender as principais modificações biogeoquímicas ao longo do tempo foram investigados os padrões espaço-temporais da estratificação e da eutrofização. Os dados de qualidade da água foram obtidos a partir de campanhas de campo complementados com dados da literatura dos últimos 15 anos. A estrutura vertical da coluna da água e o estado trófico foram avaliados pelo o índice de estratificação e o índice TRIX, respectivamente. Análises de variância foram realizadas com o objetivo de identificar possíveis variações temporais na estratificação vertical e no nível trófico. Efeitos da eutrofização nos ciclos biogeoquímicos foram verificados através de uma análise de agrupamento multidimensional (MDS) e correlações entre as variáveis relacionadas a processos físico-químicos e biológicos foram verificadas através da análise de componentes principais (PCA). Os resultados mostraram que há homogeneidade da coluna d'água em todas as regiões da laguna exceto na região central sendo observadas as maiores concentrações de nitrogênio amoniacal e as menores concentrações de oxigênio dissolvido com períodos anoxia nas águas de fundo. Foi verificada elevação do nível trófico da laguna e sua incapacidade para processar as mudanças biogeoquímicas impressas pelo avanço urbano.

Palavras-chave: TRIX; Lagunas costeiras; Estratificação; Hipóxia; Ciclos biogeoquímicos. 


\section{INTRODUCTION}

Destruction of marine ecosystems by anthropic action is a global phenomenon that is attaining alarming proportions (LOTZE et al., 2006; HALPERN et al., 2008, 2015), and one of the main causes of degradation in coastal zones is the input of nutrients from industry and agriculture (GESAMP, 2001). On the other hand, in developing countries, due to the high rate of urban occupation associated with technological deficiencies and public mismanagement, the discharge of sanitary effluents is one of the most concerning sources of pollution in coastal water bodies (MIRANDA; CASTRO; KJERFVE, 2002; DSIKOWITZKY et al., 2016; ROVERSI et al., 2016; WETZ et al. 2016).

Coastal lagoons are semi-closed transitional water environments, with high socioeconomic value, and extremely susceptible to anthropic action. Choked lagoons in particular are characterized by high residence time associated with low water renewal rates, which leads to the accumulation of nutrients, sediments and organic matter (KJERFVE, 1994; KNOPPERS; KJERFVE, 1999; MIRANDA; CASTRO; KJERFVE, 2002; EKAU; KNOPPERS, 2003; BIANCHI, 2006;). In these environments, the excessive discharge of nutrients causes changes that lead to increasing levels of eutrophication, resulting in a decline of biodiversity, changes in the food chains, harm to human health and economic and social losses that are difficult to measure (NIXON, 1995; GASALLA; ROSSI-WONGTSCHOWSKI, 2004; TUNDISI, 2003; RABALAIS et al., 2009).

Lagoa da Conceição (LC), located on the east coast of the island of Santa Catarina, is an outstanding source of resources and ecosystem services, and various species of marine organisms shelter and reproduce there (BRANCO; VERANI, 1997; LEDO, 1999; RIBEIRO; CLEZAR; HOSTIM-SILVA, 1999; BORGO et al., 2015). The lagoon is widely used for fishing, tourism and several sports, and is a major source of increments for various sectors of local trade and also for the municipality. However, this environment has been affected over the last few decades by the increase of disordered urban growth and a noticeable change in the use and occupation of its hydrographic basin. Population studies performed by Campanario (2007) indicate that the urban population around the lagoon grew $93.2 \%$ between 2001 and 2015 , at a rate of $6.3 \%$ a year, a growth rate that is four times higher than the $1.5 \%$ a year of the state of Santa Catarina during the same period (CAMPANARIO, 2007).

Over the last 20 years, several studies of the lagoon have provided important data to improve understanding of the evolution of anthropic impacts in this environment (FONSECA; BRAGA; EICHLER, 2002; FONSECA, 2004; FONSECA, 2006; FONTES, 2009; FONTES et al., 2011; ODRESKI, 2012; SILVA, 2013; CURY, 2016). However, the integration of these data was still lacking in knowedge regarding water quality in the lagoon. The purpose of the present study was to systematize the existing water quality data for Lagoa da Conceiçao in order to: a) evaluate the lagoonal regions as to the existence or absence of stratification in the water column; b) evaluate the temporal evolution in the region where more intense stratification processes were identified; c) describe the spatial variations and identify tendencies toward eutrophication in the lagoon based on the Trophic State Index - TRIX (VOLLENWEIDER et al., 1998) during the period from 2001 to 2015, and d) look at the dynamics of the inorganic nutrients, oxygen and phytoplankton biomass to understand the main biochemical modifications that occurred in the system during the period analyzed. The integration of secondary data (Table 1), together with an in situ data survey performed in 2015, constituted a so far unheard-of effort to understand the state and trophic evolution in Lagoa da Conceição.

\section{MATERIALS AND METHODS}

\section{Area of study}

Lagoa da Conceição is a subtropical coastal lagoon located in the Municipality of Florianópolis (Figure 1),capital of the State of Santa Catarina $\left(27^{\circ} 34^{\prime} \mathrm{S} 48^{\circ} 27^{\prime} \mathrm{O}\right)$. The lagoon has a surface of $24 \mathrm{~km}^{2}$, a volume of $66,648,179 \mathrm{~m}^{3}$ and a hydrographic basin of $78 \mathrm{~km}^{2}$ (AEROCONSULT, 2000).

The population is distributed mainly among five neighborhoods around the Lagoon (Figure 1), in the north, Rio Vermelho, along the Canal da Barra, and south in Porto, Canto and Centro.

The only connection between the lagoon and the ocean is a meandering channel $2.8 \mathrm{~km}$ long, between 1 and 6 meters deep and between 5 and 25 meters wide (ROCHA, 2007). The inlet channel (Canal da Barra) acts as a filter of the astronomic tide and the level of the lagoon responds primarily to the variations in the ocean level within the meteorological range (GODOY, 2009). When there is no wind, the hydrodynamics is ruled by the hydrological inputs distributed over the north, west and south

Table 1. Reference of the secondary data used for the historical analysis of the water quality of Lagoa da Conceição. Data were obtained referring to the following parameters: temperature $\left({ }^{\circ} \mathrm{C}, \mathrm{T}\right)$, salinity (PSU, S), concentration of dissolved inorganic phosphorus ( $\mu \mathrm{g} / \mathrm{L}, \mathrm{PID})$, ammonium ( $\mu \mathrm{g} / \mathrm{L}, \mathrm{NH} 4-)$, nitrate( $\mu \mathrm{g} / \mathrm{L}, \mathrm{NO} 3-2)$, chlorophyll -a ( $\mu \mathrm{g} / \mathrm{L}, \mathrm{Cl}-\mathrm{a})$ and dissolved oxygen $(\mathrm{mg} / \mathrm{L}, \mathrm{OD})$. The hydrodynamic parameters obtained were velocity and direction of the current and water surface level.

\begin{tabular}{|c|c|c|c|}
\hline YEAR & Author & $\begin{array}{l}\text { Method/N } \\
\text { of samples }\end{array}$ & Parameters \\
\hline 2001 & $\begin{array}{l}\text { Fonseca } \\
(2004,2006), \\
\text { Fonseca, Braga } \\
\text { and Eichler 2000) }\end{array}$ & $\begin{array}{l}\text { Sampling in the entire } \\
\text { lagoon / } N=118\end{array}$ & Water quality \\
\hline 2003 & Fontes (2004) & $\begin{array}{l}\text { Sampling in the entire } \\
\text { lagoon / } \mathrm{N}=155\end{array}$ & Water quality \\
\hline 2005 & Fontes (2009) & $\begin{array}{l}\text { Sampling in the entire } \\
\text { lagoon / } \mathrm{N}=44\end{array}$ & Water quality \\
\hline 2007 & $\begin{array}{l}\text { Fontes (2009), } \\
\text { Fontes et al. (2011) }\end{array}$ & $\begin{array}{l}\text { Sampling in the entire } \\
\text { lagoon / } \mathrm{N}=70\end{array}$ & Water quality \\
\hline 2012 & $\begin{array}{l}\text { Bier (2013), } \\
\text { Odreski (2012) }\end{array}$ & GIS/Modelling & Hydrology \\
\hline 2013 & Silva (2013) & Modelling & $\begin{array}{l}\text { Hydrodynamic } \\
\text { circulation }\end{array}$ \\
\hline 2015 & In situ & $\begin{array}{l}\text { Sampling in the entire } \\
\text { lagoon / } \mathrm{N}=64\end{array}$ & Water quality \\
\hline
\end{tabular}


banks of the water body. (ANDRADE, 2001; ODRESKI, 2012; SILVA, 2013).

Residual transport of water takes place in the latitudinal direction from the extremes to the center of the lagoon, with runoff to the sea via the inlet channel (SILVA, 2013). Based on residual flow fields, the aforementioned author also identified the presence of cyclonic (small depth) and anticyclonic (greater depth) gyres at 7 points in the lagoon (Figure 2).

The conditions presented by the anticyclonic gyres are favorable to the accumulation of particles in the central south regions, and consequently the increased gradients of nutrient and particulate matter concentration towards the bottom. In turn, the cyclonic gyres result in the resuspension of dissolved nutrients from the bottom to the surface, where an increment of primary productivity is expected (GÓMEZ; GÓMEZ; BULGAKOV, 2008).

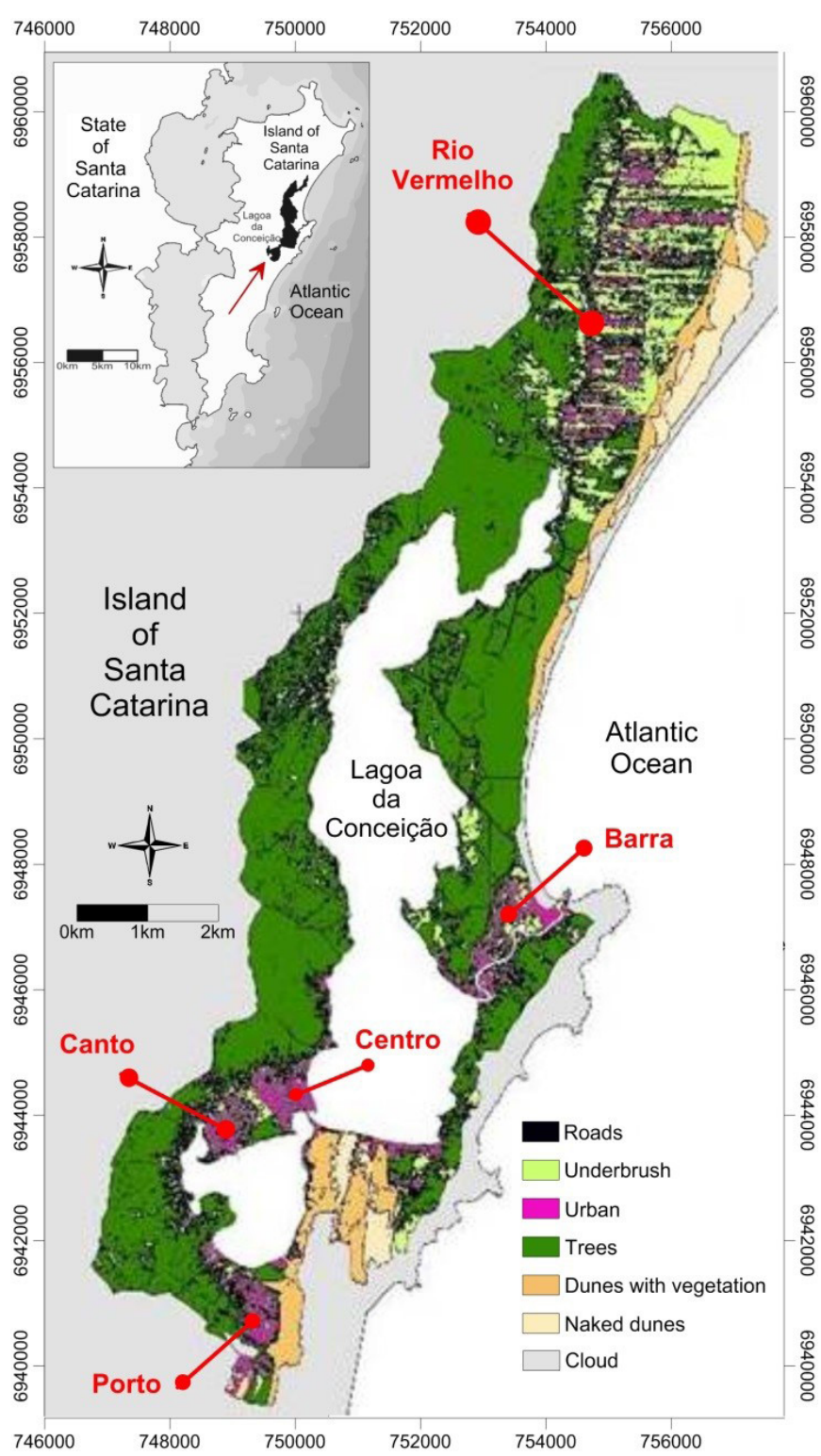

Figure 1. Location and occupation map of the hydrographic basin of Lagoa da Conceição. Source adapted from Bier (2013).

\section{Data survey}

In order to evaluate the oceanographic conditions of the system, four campaigns were held in 2015 to collect data (Mar/27, Aug/19, Aug/27 and Sep/28) that covered the entire area of the lagoon at 8 sampling points, 2 points per region (Table 2 ). The depth was measured for each point using a FishTaker echobathymeter. Data on temperature and salinity in the water column were collected every $0.5 \mathrm{~m}$ with the help of a model CastWawy CTD profiler of YSI. For the analysis of nutrients and chlorophyll-a, water samples were collected on the surface and bottom using a Van Dorn bottle with horizontal closing.

The samples were preserved in appropriately acclimated thermal boxes which were protected from light until they were

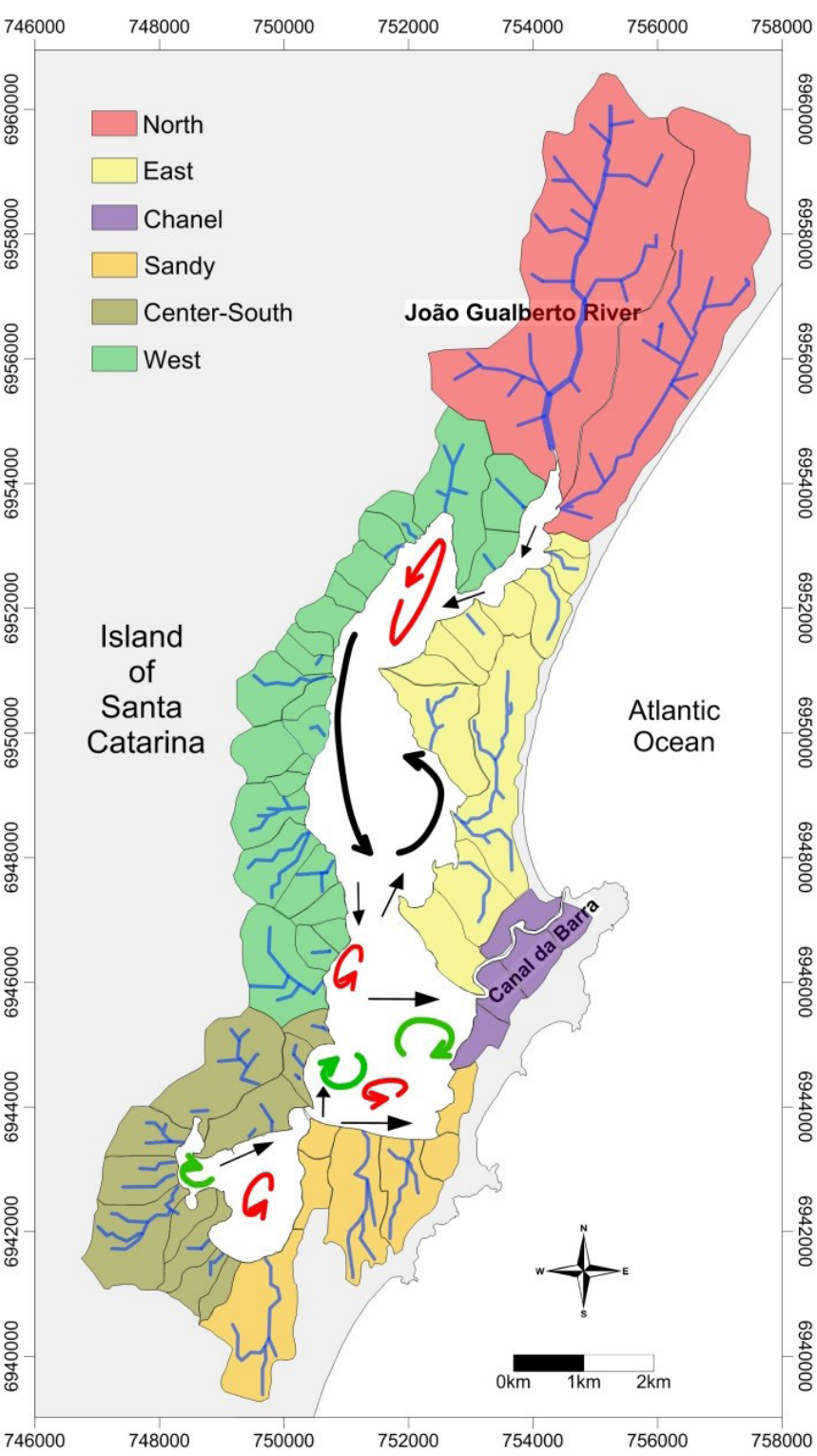

Figure 2. Map of the hydrographic network of the basin and the residual circulation pattern in the body of the lagoon. The black arrows indicate residual flows from the extremes to the center-east part of the lagoon. Green and red arrows indicate the presence of cyclonic and anticyclonic gyres, respectively. 
processed in the Laboratory according to Lana et al. (2006). Once they were in the laboratory, the water samples were filtered using the $47 \mathrm{~mm}$ glass microfiber filter GF-5, as described by Strickland and Parson (1972). After filtering, the samples were frozen at $-20^{\circ} \mathrm{C}$ until the time of analysis. Since it was a fraction that could be assimilated by the phytoplankton, nitrogen was quantified in the dissolved inorganic form (DIN). DIN was estimated by the sum of concentrations of ammoniacal-N $\left({ }_{\mathrm{NH}}\right)$. nitrate $\left(\mathrm{NO}_{3}\right)$ and nitrite $\left(\mathrm{NO}_{2}\right)$, and these were estimated by colorimetric methods with a $0.7 \mu \mathrm{g} . \mathrm{L}^{-1}$ precision (GRASSHOLF; KREMLING; EHRHARDT, 1999). Orthophosphate, dissolved inorganic phosphorus (DIP), and silicate $(\mathrm{SiOH})$ were quantified by the colorimetric method with a precision of $0.9 \mu \mathrm{g} . \mathrm{L}^{-1}$. The absorbances were read in a dual beam Hitachi UV-290 spectrophotometer, based on calibration with certified solutions of Merck® (GRASSHOLF; KREMLING; EHRHARDT, 1999). The phytoplankton biomass (Chlorophyll-a) was quantified by fluorimetry, with the help of a Turner Designer-Trilogy fluorimeter (STRICKLAND; PARSON, 1972). The $\mathrm{pH}$ and dissolved oxygen were measured with a model Ecosense YSI pHmeter, and with a model Handlab OX12 Schott oxymeter..

Information about the lagoon hydrodynamics and morphology was obtained from Odreski (2012) and Silva (2013). Data on the water quality of Lagoa da Conceição were obtained in the literature referring to past studies performed in 2001, 2003, 2005 and 2007. A more detailed description of the bibliography is presented in Table 1. Complementary data referring to the growth and population density of the neighborhoods were obtained from Campanario (2007) and data on the coverage of the sanitary sewerage system were obtained from MPB Engenharia (2008).

\section{Data selection}

Since Florianópolis is an area of tourism, its population during the high season (December to February) may be three times greater than the resident population. According to projections by Campanario (2007), the population density in the urbanized area of the lagoon hydrographic basin for 2015 was from 1200 to 3600 inhab $/ \mathrm{km}^{2}$ during the low and high season, respectively. In order to prevent noise introduced by the floating population, only data from the low season months (March to November) were selected. To standardize the sampling effort, 32 data per year were selected (limitation found in 2005), seeking

Table 2. Distribution of the number of samples used to analyze the spatial and temporal tendency of Lagoa da Conceição for each region: North, Center-North, Central and South. The months sampled and the number of sampling stations per year of study are given.

\begin{tabular}{|c|c|c|c|c|c|c|c|}
\hline \multirow{2}{*}{ YEAR } & \multicolumn{5}{|c|}{ Data per region } & \multirow{2}{*}{$\begin{array}{l}\text { Months } \\
\text { sampled }\end{array}$} & \multirow{2}{*}{$\begin{array}{l}\text { Sampling } \\
\text { Stations }\end{array}$} \\
\hline & $N$ & $C N$ & $C$ & $S$ & Total & & \\
\hline 2001 & 7 & 3 & 10 & 12 & 32 & $5,8,9,11$ & 17 \\
\hline 2003 & 8 & 8 & 8 & 8 & 32 & 6,7 & 17 \\
\hline 2005 & 8 & 8 & 8 & 8 & 32 & 7 & 17 \\
\hline 2007 & 4 & 4 & 13 & 11 & 32 & 4,5 & 16 \\
\hline 2015 & 8 & 4 & 10 & 10 & 32 & $3,8,9$ & 16 \\
\hline Total & 35 & 27 & 49 & 49 & 160 & $4,5,6,7,8,9,11$ & 83 \\
\hline
\end{tabular}

whenever possible to obtain 8 items of data for each region of the lagoon (Table 2).

\section{Hydrodynamic sectors}

Based on the residual circulation pattern of the water in the lagoon (Figure 2), eight hydrodynamic sectors were defined and shown in Figure 3.

- N1 - Extreme North sector: small depth and hydrological influence of the João Gualberto river sub-basin (largest area of the hydrographic basin);

- N2 - North sector; medium depth with low flow velocity and accumulation of particles due to the presence of an anticyclonic gyre;

- CN1 - North Center sector: great depth and residual flow in the southern direction;

- CN2 - North Center sector: small depth and residual flow in the South to North direction, with influence from the inlet channel(Canal da Barra);

- $\mathrm{C} 1$ - Central Sector: low depth and dispersion forced by the contribution of water from sector $\mathrm{CN}$ and the Canal da Barra;

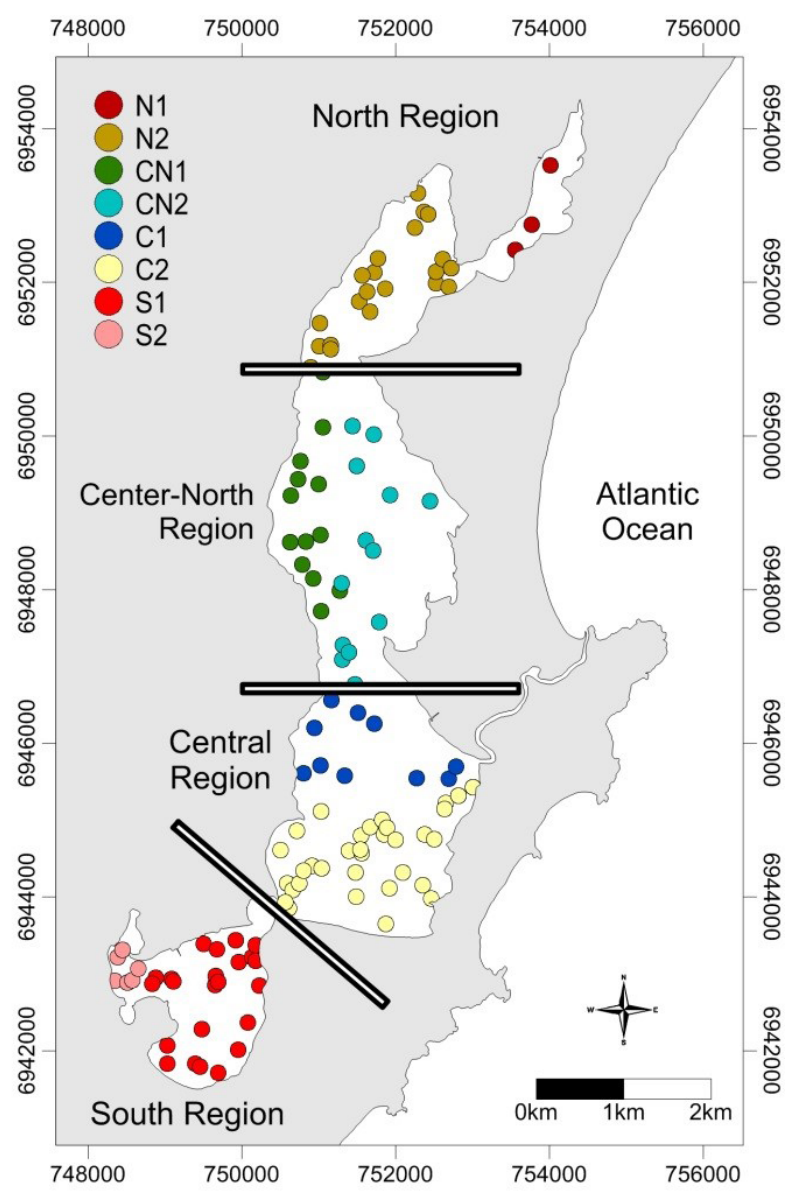

Figure 3. Distribution of the sampling points in the eight hydrodynamic sectors of the lagoon. 
- C2 - Central sector: great depth with low flow velocities and the presence of an anticyclonic gyre that intensifies particle accumulation;

- S1 - South sector: small depth and hydrological influences of the most densely populated basins of the hydrographic basin;

- S2 - South Sector: great depth, low flow velocities and accumulation of particles due to the presence of an anticyclone gyre.

\section{Data processing}

The specific mass of water was calculated for all samples using temperature and salinity data with the package of routines in MatLab TEOS 10 (MCDOUGALL; FEISTEL; MILLERO, 2010).

In order to look at the homogeneity of the water masses, the stratification index of the water column was calculated by the difference between specific mass of surface and bottom, according to Miranda, Castro and Kjerfve (2002).

The eutrophication process in the body of water was estimated by the Trophic State Index, TRIX. The index proposed by Vollenweider et al. (1998) allows evaluating the nutritional status and anthropic impacts on bodies of water. The TRX idex is calculated from Equation 1:

TRIX $=\frac{[(\log (\text { Chla. } \mathrm{aD} \% \mathrm{O} . \mathrm{N} . \mathrm{P})-(\mathrm{a})]}{\mathrm{b}}$

Where:

Chla. Chlorophyll-a [mg.m $\left.{ }^{-3}\right]$ as an objective way of measuring the primary production of phytoplankton;

$\mathbf{a D} \% \mathbf{O}$. Dissolved oxygen as an absolute deviation [\%] of saturation, as a way of measuring the balance between production and respiration;

N. Dissolved inorganic nitrogen as $\mathrm{N}-\left(\mathrm{NO}_{3}^{-2}+\mathrm{NO}_{2}+\mathrm{NH}_{4}^{-}\right)[\mu \mathrm{g} / \mathrm{L}]$; P. Dissolved inorganic phosphorus as $\mathrm{P}^{-\mathrm{PO}_{4}^{-3}}[\mu \mathrm{g} / \mathrm{L}]$.

Parameters $\mathbf{a}$ and $\mathbf{b}$ are determined based on the scale of values of the data. In this study the following were determined: $\mathrm{a}=-1.5$ e $\mathrm{b}=2$.

According to TRIX, estuarine waters can be classified by comparing bodies of water with similar characteristics, or according to the values proposed by Penna, Capellacci and Ricci (2004) (Table 3).

Based on the results obtained using TRIX a clustering analysis was performed using the cluster complete linkage method to look at the dissimilarity of the eight hidrodynamic sectors. The distinct groups were verified over time using the Kruskall-Wallis test $(p=0.05)$. The Kolmogorov-Smirnov and Wald-Wolfowitz tests were performed to corroborate the transition periods of the trophic state.

In order to verify the effects of eutrophication on the biogeochemical cycles, a multidimensional scaling analysis MDS) was performed, based on a similarity matrix of the following variables: temperature, salinity, DIN, DIP, chlorophyll-a, $\mathrm{pH}$ and DO. The analyses were generated by the PRIMER statistical package (ANDERSON et al., 2008). Simple Pearson correlation analyses and Spearman's nonparametric analyses were generated
Table 3. Classification of the trophic level according to the values of the TRIX index.

\begin{tabular}{clc}
\hline TRIX & \multicolumn{1}{c}{ Condições } & Estado Trófico \\
\hline TRIX $<2$ & $\begin{array}{l}\text { Low nutrient concentration and } \\
\text { primary productivity }\end{array}$ & Oligotrophic \\
\hline $2 \leq$ TRIX $>4$ & $\begin{array}{l}\text { Moderate nutrient concentration } \\
\text { and primary productivity }\end{array}$ & Mesotrophic \\
\hline $4 \leq$ TRIX $>6$ & $\begin{array}{l}\text { High nutrient concentration and } \\
\text { primary productivity }\end{array}$ & Eutrophic \\
\hline $6 \leq$ TRIX $>8$ & $\begin{array}{l}\text { Very high nutrient concentration } \\
\text { and primary productivity }\end{array}$ & Hiper- Eutrophic \\
\hline
\end{tabular}

to look at the correlation between the physical-chemical and biological variables.

The relationship between the ecological variables was verified by the Principal Components Analysis (PCA), performed on all the data sampled, signaling the regions of the lagoon and periods sampled.

\section{RESULTS AND DISCUSSION}

\section{Spatio temporal evolution of water column stratification}

The central sector (C2) showed a significant difference from the other sectors, presenting a stratification of the vertical structure of the water column and a contrast with the other sectors that did not present stratification (Figure 4).

In general, lagoon stratification over time presented an increase both of mean and of variance (Figure 5).

Despite the gradual increase in the stratification index throughout the lagoon, the mean values presented a situation of absence of vertical stratification. The increase of variance is a consequence of the data observed in sector $\mathrm{C} 2$, which provided a significant increase of the index from 2005 onwards (Figure 6).

Beginning in 2005, stratification in sector C2 increased significantly (Kruskal-Wallis test, $p=0.01$ ), reaching an order of $700 \%$ in 2015 (Figure 6). The post-hoc test for the data of this sector $(\mathrm{p}<0.05)$ showed two distinct groups, one comprising 2001, 2003 and 2005 and the other comprising 2007 and 2015, the latter period characterized as stratified. Stratification values observed for 2015 indicate the existence of two distinct masses of water, bottom and surface.

The stratification suffered a greater influence from the difference between surface and bottom than from temperature, as shown by Figures 7 and 8 .

It is observed that the temperature varied uniformly in the water column during the years monitored, however there was increased bottom salinity and possible stabilization of this value from 2005 to 2015. Likewise, a marked reduction in surface salinity in 2015 explains the high values of the stratification index in that year. Kjerfve and Magill (1989) point out that vertical stratification in coastal lagoons is a phenomenon due mainly to hydrodynamic factors, where only slightly elevated flows can favor stratification in the water column (SMITH et al., 2000). In Lagoa da Conceição 


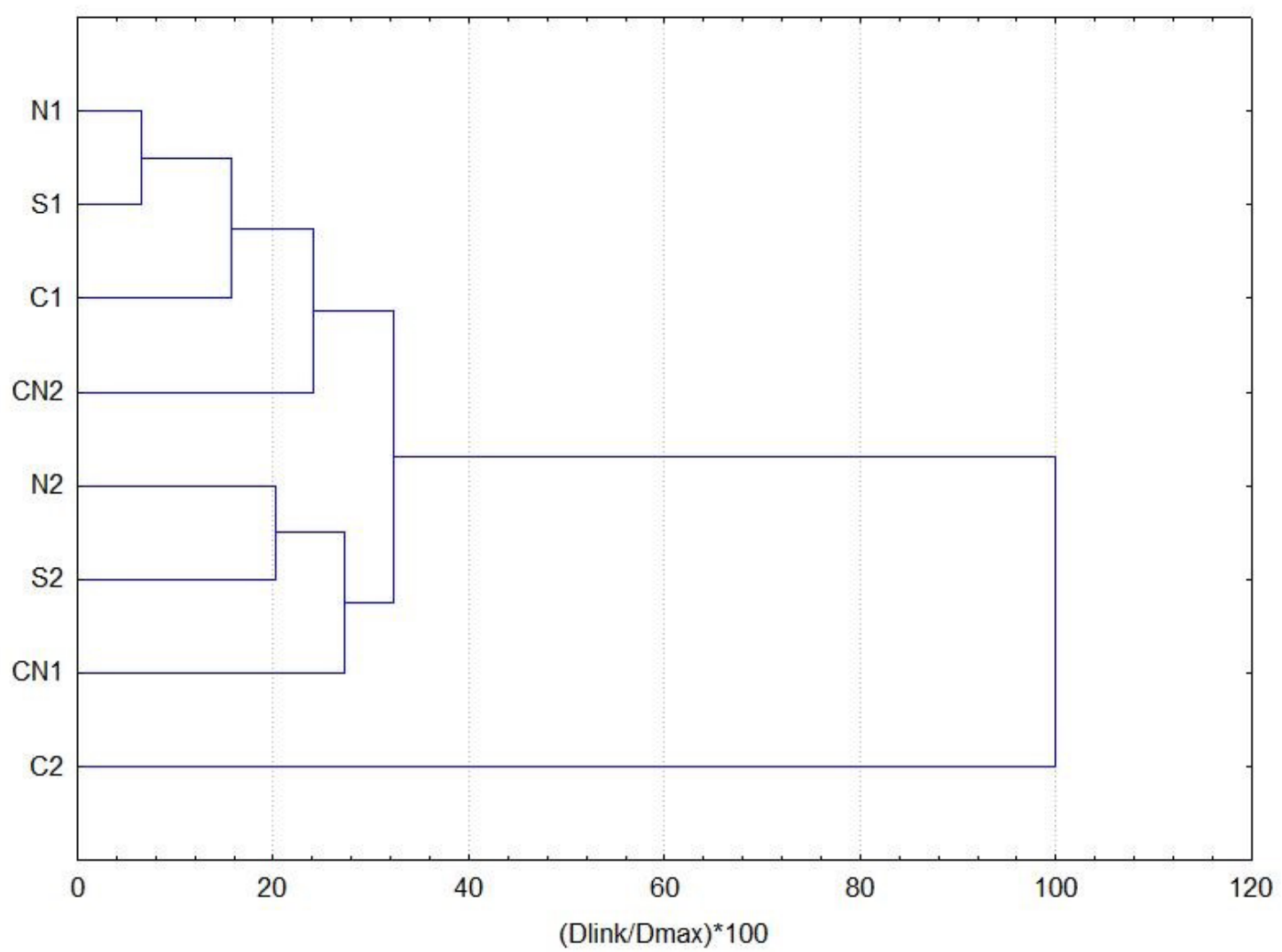

Figure 4. Clustering according to the stratification index fo the hydrodynamic sectors of Lagoa da Conceição using the complete linkage method and Euclidean distance.

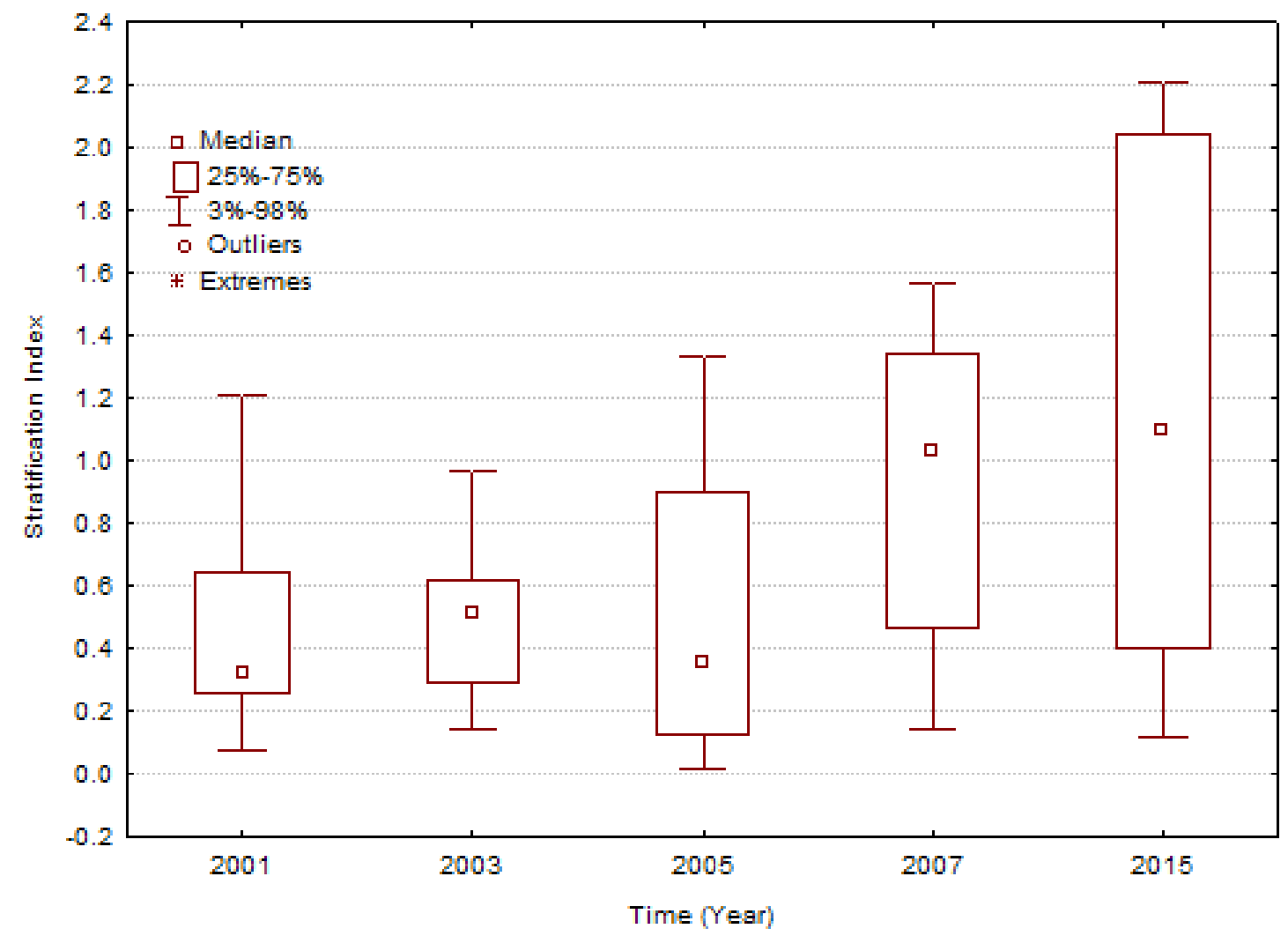

Figure 5. Temporal evolution of the stratification index in the entire lagoon over the period evaluated. From 2003 onwards a gradual increase was observed in the variance of the stratification values. 


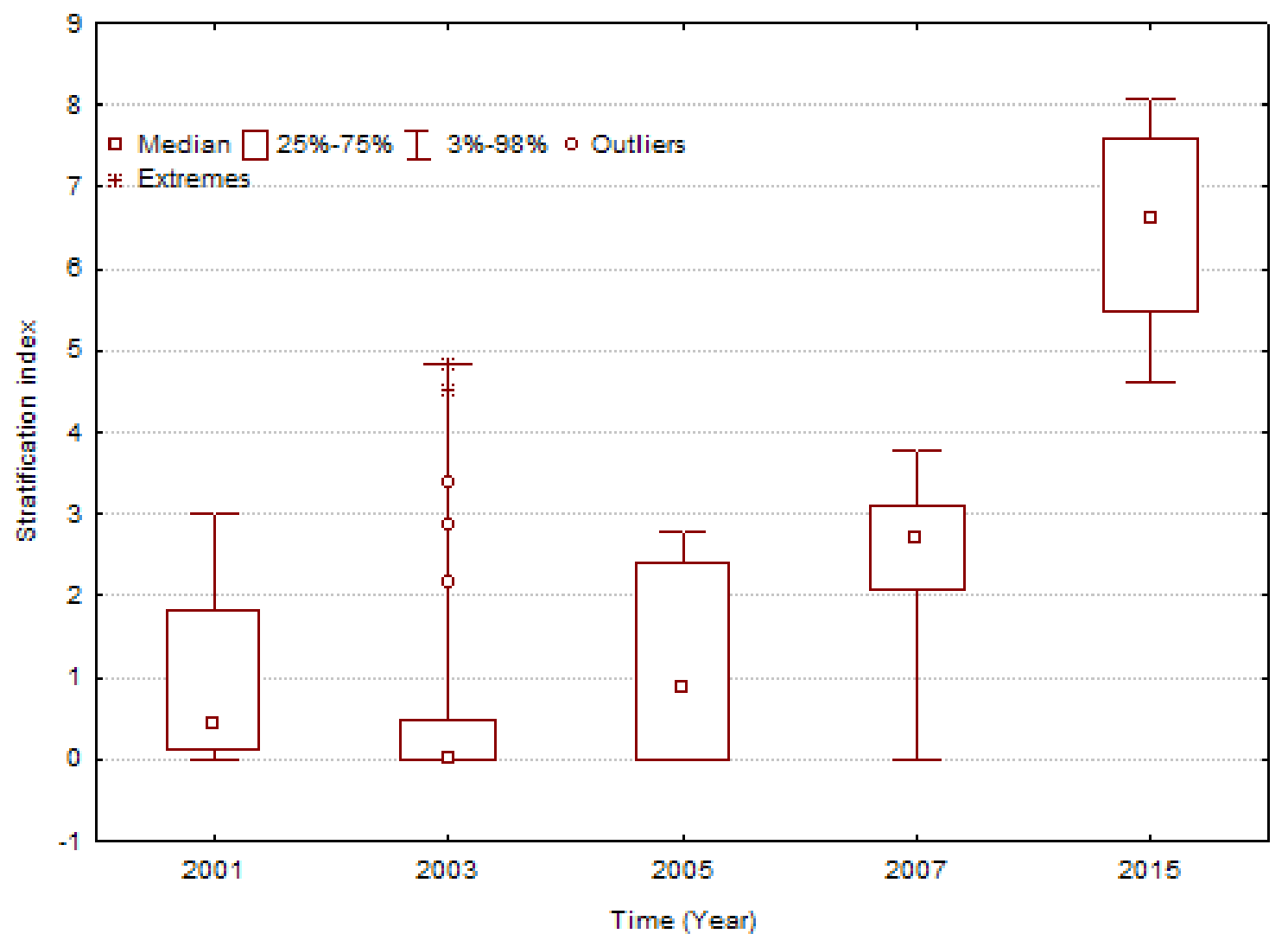

Figure 6. Evolution of the water column stratification in sector C2 of the lagoon, over the period evaluated.

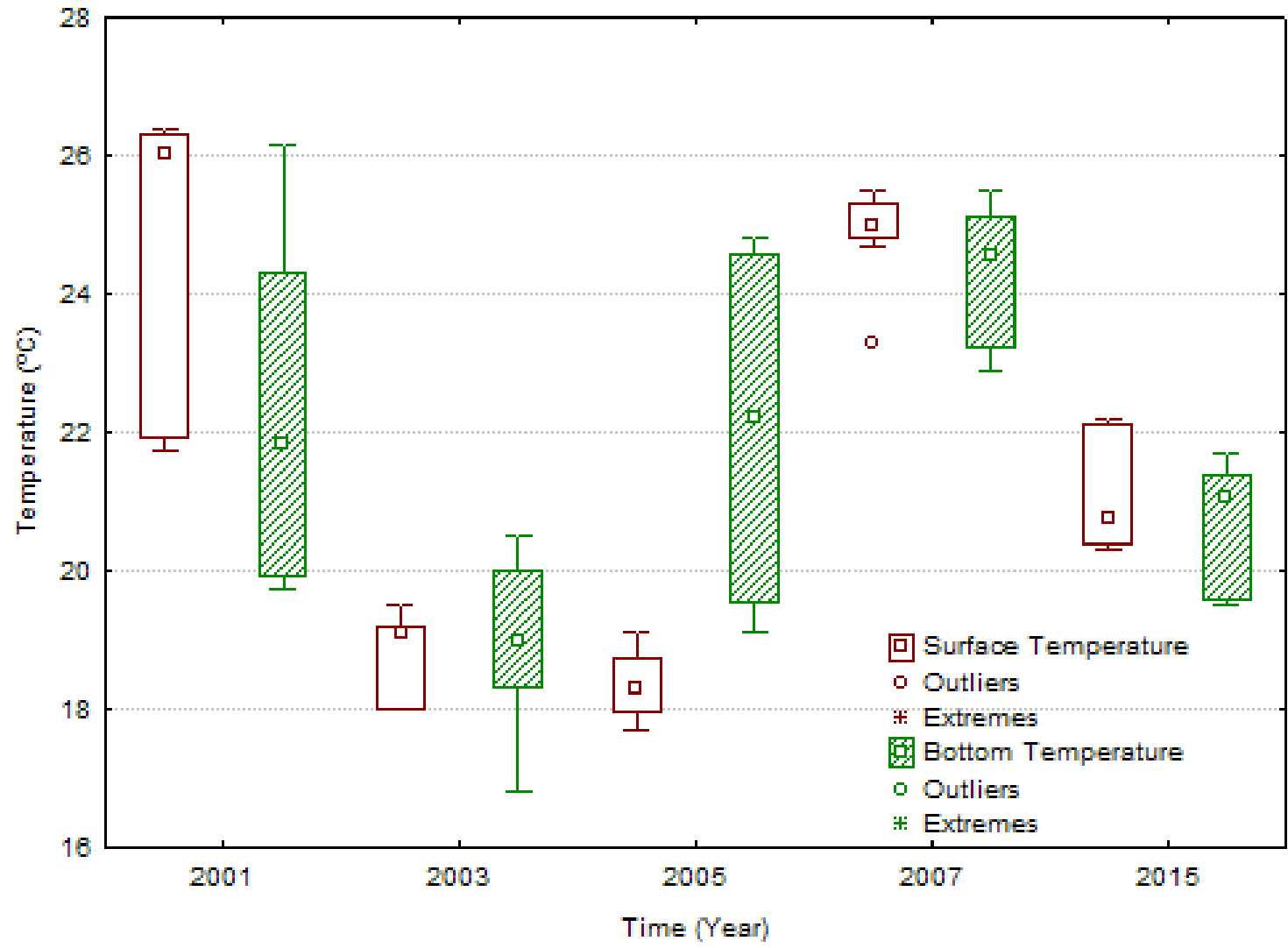

Figure 7. Evolution of the surface and bottom temperature in sector C2 for the period studied. The temperatures are homogeneous throughout the water column. 


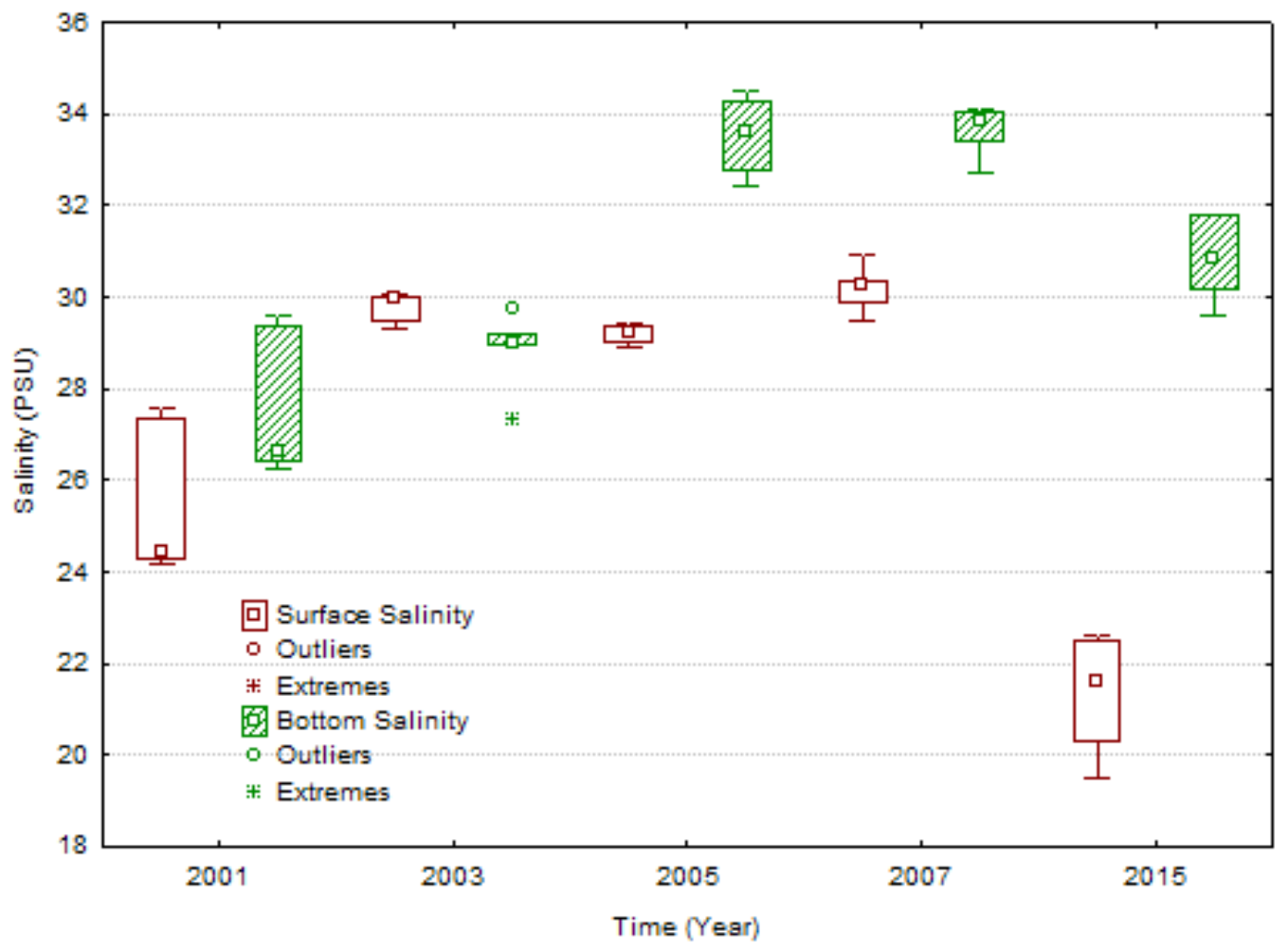

Figure 8. Evolution of surface and bottom salinity of sector C 2 for the period studied. Beginning in 2005 there is a clear difference in the salinity values of the surface and bottom.

there is little influence from the tide and slow residual velocity in sector C2 (GODOY, 2009), which favors stratification conditions.

\section{Spatial temporal evolution of the trophic state}

Based on the cluster analysis (Figure 9) two groups were analyzed regarding the level of eutrophication. The sectors under the influence of the hydrological inflows to the North (Rio João Gualberto) - sectors N1, N2, CN1, CN2 and C1 - and the sectors influenced by the hydrological contribution of the Center and the South - C2, S2 and S1. Sector S1 stood out because it presented the highest values of the trophic index (eutrophic to hyper eutrophic). This can be explained by the great urban density of the drainage basin located to the south, compared to the area of the lagoon body, and the high residence time of water in this sector, which is more than 30 days (FONSECA, 2004). In this region, the highest TRIX values were observed close to the hydrological discharge points (S1) and to the impoundment of water close to the choking point where there is a connection to the central region $(\mathrm{S} 2)$.

The TRIX values ranged from 1.6 to 5.6 indicating oligotrophic to hypereutrophic conditions. The trophic level values found in each sample are shown in Figure 10.

In the North region, the highest values of TRIX are in sector $\mathrm{N} 2$, close to the mouth of the main rivers of the hydrographic basin. Hydrological discharges from João Gualberto river flow from north to south through the deep channel (CN1) (ODRESKI, 2012; SILVA, 2013), presenting high TRIX values. On the east side, in $\mathrm{CN} 2$, the dilution caused by the residual return current close to the channel reduces nutrient concentration. Hence, due to the hydrodynamic characteristics, the North of the lagoon presents a pattern defined by higher TRIX values to East and lower values to West. In the Central region the highest values are found in the proximity of the channel which provides the connection to the South region, where an anticyclonic gyre occurs at C2, which favors the accumulation of sediments and particulate materials at the bottom. This sector had various anoxic events during the period sampled.

Beginning in 2005, Lagoa da Conceição went from a mesotrophic to an eutrophic state (Kruskal-Wallis test, $p=0.01$ ). The Kolmogorov-Smirnov $(p \leq 0.001)$ and Wald-Wolfowitz $(p \leq 0.001)$ tests showed that the period from 2001 to 2005 remained stable with mean TRIX values around $2.8(\sigma=0.46)$. From 2005 onwards, an increase in mean values was observed to $4.05(\sigma=0.76)$ as shown in Figure 11.

The trophic index - TRIX has been effective in diagnosing the state of eutrophication in various coastal lagoons (BRANDINI; FERNANDES, 1996; COELHO; GAMITO; PÉREZ-RUZAFA, 2007; CAÑEDO-ARGÜELLES et al., 2012; COTOVICZ, 2013; ACQUAVITA et al., 2015). The results obtained by these authors showed that the index satisfactorily represented the variations found in the concentrations of the dissolved forms of nitrogen, and total phosphorus, of the reduced forms of nitrogen, of the reduction of dissolved oxygen concentrations and increased concentrations of chlorophyll - -a.

In Lagoa da Conceição the concentrations of dissolved inorganic nitrogen(DIN) and inorganic phosphorus (DIP) increased on the order of 10 times between the two periods 


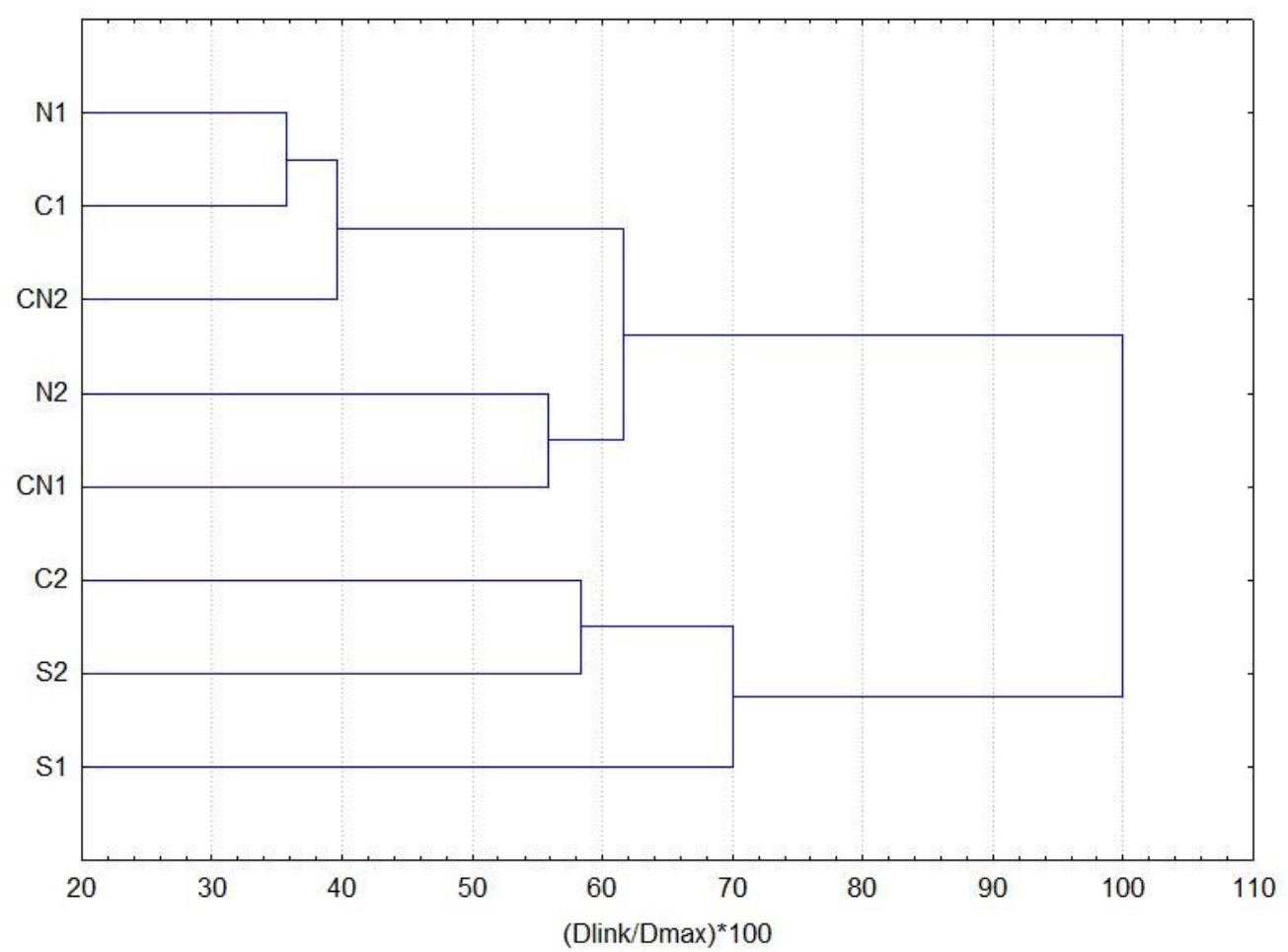

Figure 9. Dendrogram of the trophic index (TRIX) for the period sampled in the eight hydrodynamic sectors.

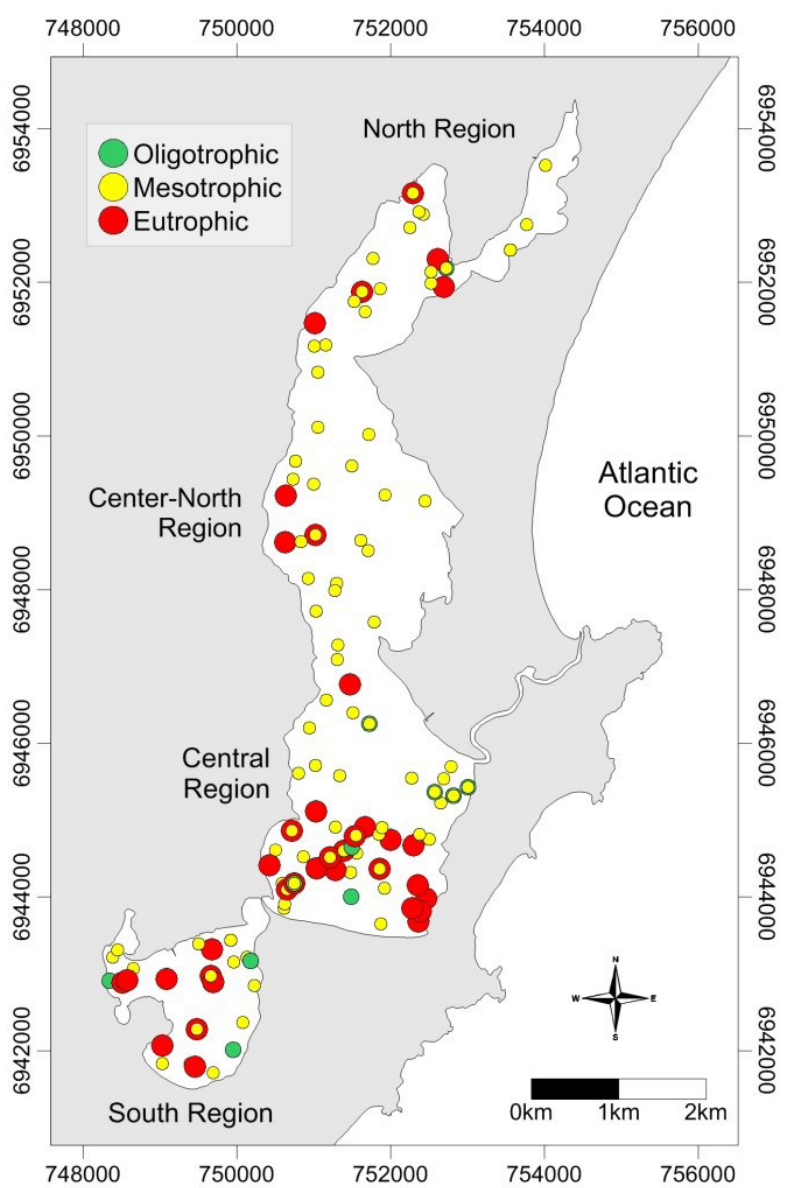

Figure 10. Results obtained from TRIX for the sampling points throughout Lagoa da Conceição during the period evaluated. indicated (Figures 12). It should be underscored that the waters of the North and Center North subsystem presented a greater increase for DIN, and those of the South and Central subsystem presented a greater increase for DIP.

A 10-fold increase was found in the DIN and DIP values from the first to the second period, and the localities of the North and Center North subsystem presented the greatest increase for DIN and the South and Central subsystems presented the greatest increase for DIP.

The increase in the reduced form of nitrogen (ammoniacal $\mathrm{N}$ ) is considered an indicator of anthropic impact in various coastal bodies of water around the world (NIXON, 1995; RABALAIS et al., 2009, 2010). The values found for the ratio of reduced form $\left(\mathrm{NH}_{4}\right)$ to total dissolved inorganic form (DIN) increased gradually until 2007, varying from 30\% in 2001 to $90 \%$ in 2007 (Figure 13). A drop in these values was also observed in average terms in 2016, concomitantly to an increased variance. This shows a great change in the biochemical dynamics of nitrogen in the body of water. The contribution of close to $80 \%$ of the reduced form of $\mathrm{N}$ for the total pool of DIN was already observed in 2003, when the hydrographic basin population became greater than 30 thousand inhabitations (based on the population estimate done based on Campanario (2007). The year 2015 was a period characterized by the occurrence of the El Niño phenomenon which brings more intense rainfall to the region of the study. This may have favored the dilution of the lagoon waters and also their oxygenation on the surface, stimulating the nitrification process.

Beginning with MDS there is a separation of groups by sampling periods. Figure 14A presents the year of collection on a gray scale, the letters indicate the period, the hydrodynamic sector and the location of the samples in terms of surface and 


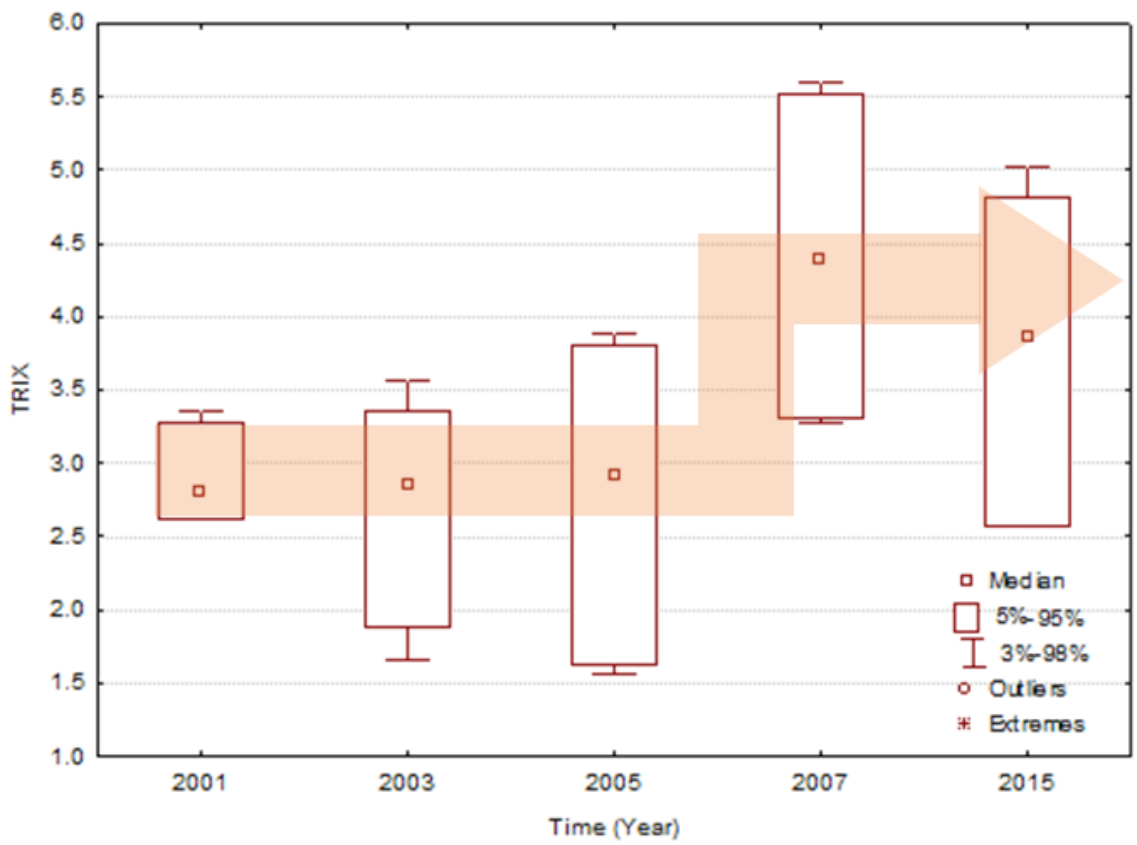

Figure 11. Temporal evolution of the TRIX values for Lagoa da Conceição during the monitored period. The arrow shows the significant increase of the trophic level from 2007 onwards.
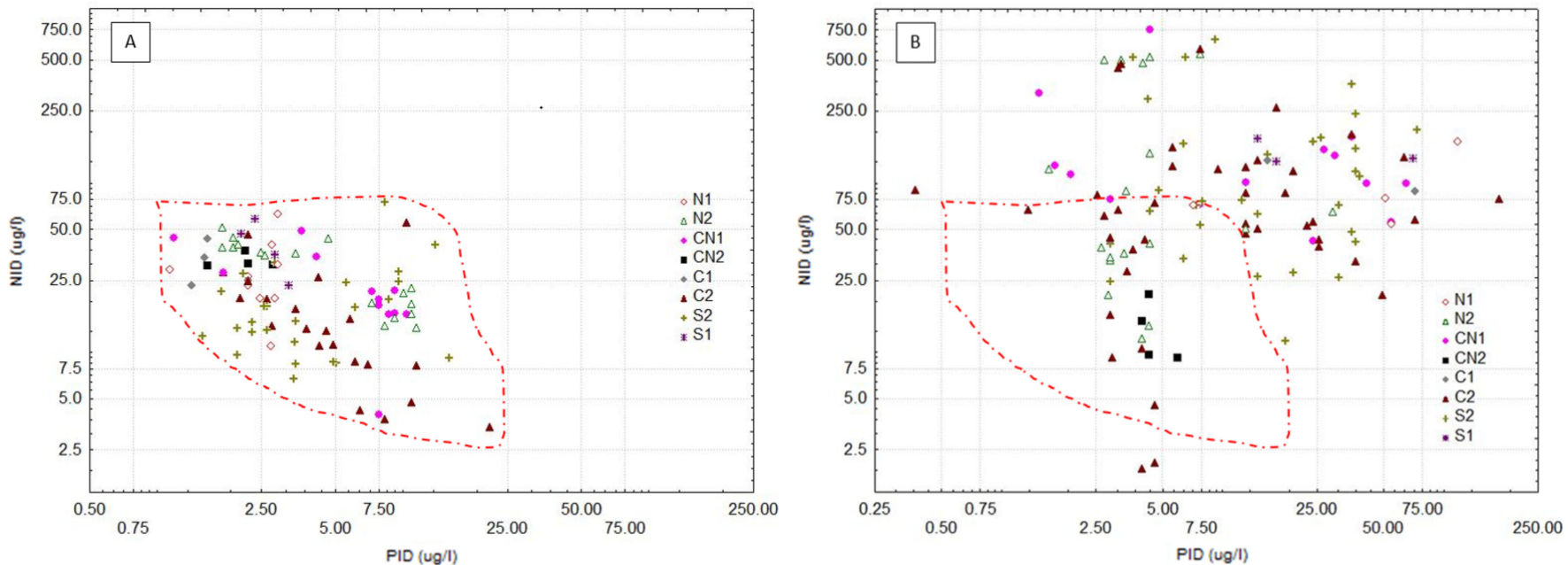

Figure 12. DIN and DIP concentration in Lagoa da Conceição, (A) Values observed in 2001, 2003 and 2005 referring to the mesotrophic period; (B) Values observed in 2007 and 2015 (eutrophic period). The dashed line that delimits the area of the graph that represents the concentrations observed in the mesotrophic period is highlighted.

bottom for the stratified localities (Central). The graph shows that the variables concerning the samples of the mesotrophic period are grouped more cohesively in the upper portion $f$ the graph (horizontal dotted line). The samples of the eutrophic period form more dispersed groups evidencing the more heterogeneous character of the lagoon in the second period. The groups formed from 2007 onwards show a sectorization of the lagoon, and the samples from the south and the bottom of the Central sector (anoxic zone) are more evident. The latter is highlighted in the graphs by the dotted globe.

The dispersion of the data during the second period evidences the increase in chlorophyll-a and the reduction of the DO levels (Figure 14B, C). This suggests a change in the nutrient cycle and a deficiency of the body of water in depurating organic matter and nitrification, which could be corroborated by the increase in reduced forms of nitrogen (Figure 13). Hypoxia and anoxia events induced by eutrophication processes are documented for coastal bodies of water worldwide (RABALAIS et al., 2010).

The inverse relationship $(\mathrm{R}=-0,20, \mathrm{p}<0.05)$ between the $\mathrm{DO}$ concentration and density of the lagoon water indicates that the DO concentrations diminished as the specific mass of water density increased, which reached higher values in the bottom waters of the Central sector.

Recently, Diaz and Rosenberg (2008) compiled 400 coastal systems worldwide that presented periodical or permanent anoxic events, including Conceição Lagoon in the study. In Brazil various 


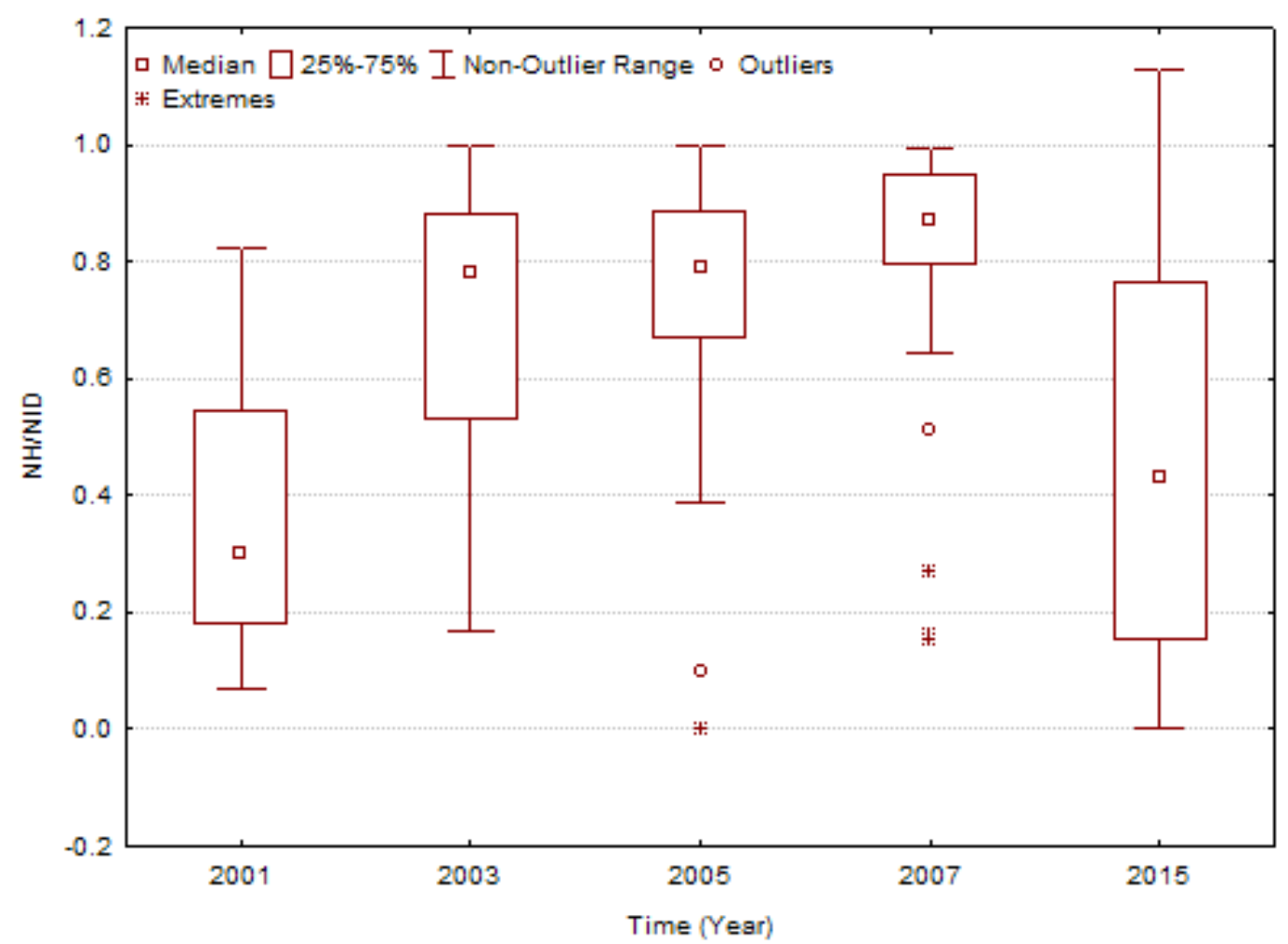

Figure 13. Proportional increase of the reduced forms of nitrogen in Lagoa da Conceição during the period evaluated.

coastal lagoons presented hypoxic to anoxic events and the intensity of these events is determined by the degree of anthropic pressure, time of residence of the water and also by natural phenomena such as coastal resurgences (BRICKER et al., 1999; RABALAIS et al., 2010; RABALAIS et al., 2009; FERRERA et al., 2005; COSTA; BARLETTA, 2016).

The separation between the mesotrophic and eutrophic periods was also correlated to the increase of phytoplankton biomass, which may be considered an indication of increased primary production. The non parametric correlation of Spearman between chlorophyll-a and DIN was 0.47 ( $p<0.05)$, evidencing the increase of the microalgal biomass based on environmental enrichment by nitrogen.

\section{EFECTS OF EUTROPHICATION ON THE BIOGEOCHEMICAL CYCLES}

The first principal component of the PCA presented an eigenvalue of 1.8 approximately accounting for $30 \%$ of the total data variance. The second component presented an eigenvalue of 1.5 acountinig for $25 \%$ of the data variation. The first component presents a negative correlation with the DO concentration and positive correlations with NH/DIN and DIP (Table 4), showing that it is the component that represents the organic matter mineralization process. This results in an increment of the concentrations of dissolved nutrients, in the case of nitrogen in the form of the ammoniacal $\mathrm{N}$ (sanitary effluent) and a reduction in the concentrations of dissolved oxygen.
The second component presents a significant correlation with DIN, Chlorophyll and an inverse correlation with the specific mass of water, indicating that it is the component that represents primary production, obtaining greater values on the surface of the water column, there the greatest incidence of light occurs.

Beginning with PCA, a spreading of the data is observed in the first and second principal component (Figure 15). In the first component (mineralization), the Central and South regions are identified, and have the highest TRIX values related to the input of nutrient loads via domestic sewage. In the second component (primary production), the outstanding sectors are North and Center North. The samples of the first period, mesotrophic, are located at the Center of the graph, which means that there was less variability among data, as was observed in MDS.

Lagoon eutrophication has been documented as an effect of human population growth in urban centers with a deficient domestic effluent treatment system, provoking environmental impacts including: anoxia and hypoxia (SMITH et al., 2000; RABALAIS et al., 2009, 2010) proliferation of toxic algae and death of aquatic organisms (WITEK; PLINSKI, 2000; FAUST; GULLEDGE, 2002; HEILEMAN; GASALLA, 2004; GASALLA; ROSSI-WONGTSCHOWSKI, 2004; GLIBERT et al., 2005) loss of batheability and increased waterborne diseases (FREITAS DE MAGALHÃES et al., 2001; RODRIGUES; LORENZZETTI, 2001; RODRIGUES et al., 2016); reduction of biodiversity (BRICKER et al., 1999; CLOERN, 2001; GLIBERT et al., 2010). These impacts are found in various Brazilian lagoons (SMITH et al., 2000; SANTORO; RICCI; ENRICH-PRAST, 2012; COTOVICZ, 2013), including Lagoa da Conceição as reported in the present study. 

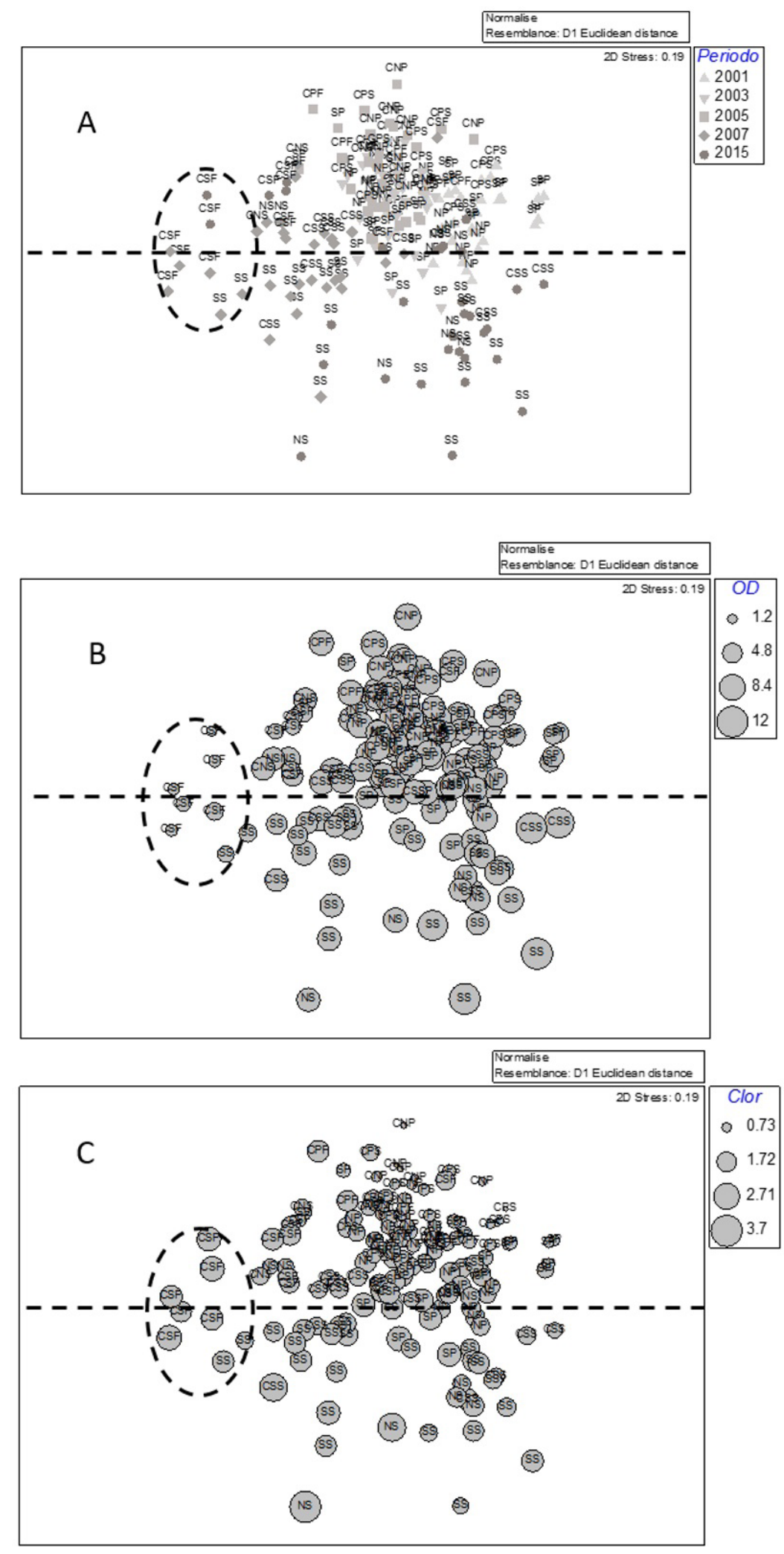

Figure 14. MDS of environmental parameters for the period (from 2001 to 2005) The letters indicate the period, the hydrodynamic sector and the location of the samples in terms of surface and bottom for the stratified localities (Central). The dashed line separates the two periods, the first $(\mathrm{P})$ mesotrophic period and the second $(\mathrm{S})$ eutrophic. The circle contains the bottom samples of the central region of the lagoon in the second period. (A) In gray scale represents the year of collection; (B) In scale of sizes for dissolved oxygen concentration (mg.L-1); (C) In scale of size for concentration ( $\mu$ g.L-1) of Chlorophyll-a, where: NP - North First Period; NS- North Second Period; CNP- Center North First period; CNS- Center North Second Period; CSP- Central Surface First Period; CFP- Central Bottom First Period; CSS- Central Surface Second Period; CFS- Central Bottom Second period; SP- South First period; SS- South Second. 
- North Sector - Period 1

$\diamond \quad$ North Central Sector- Period 1

口 Central Sector- Period 1

$\Delta$ South Sector - Period 1
- North Sector- Period 2

- North Central Sector- Period 2

- Central Sector- Period 2

- South Sector - Period 2

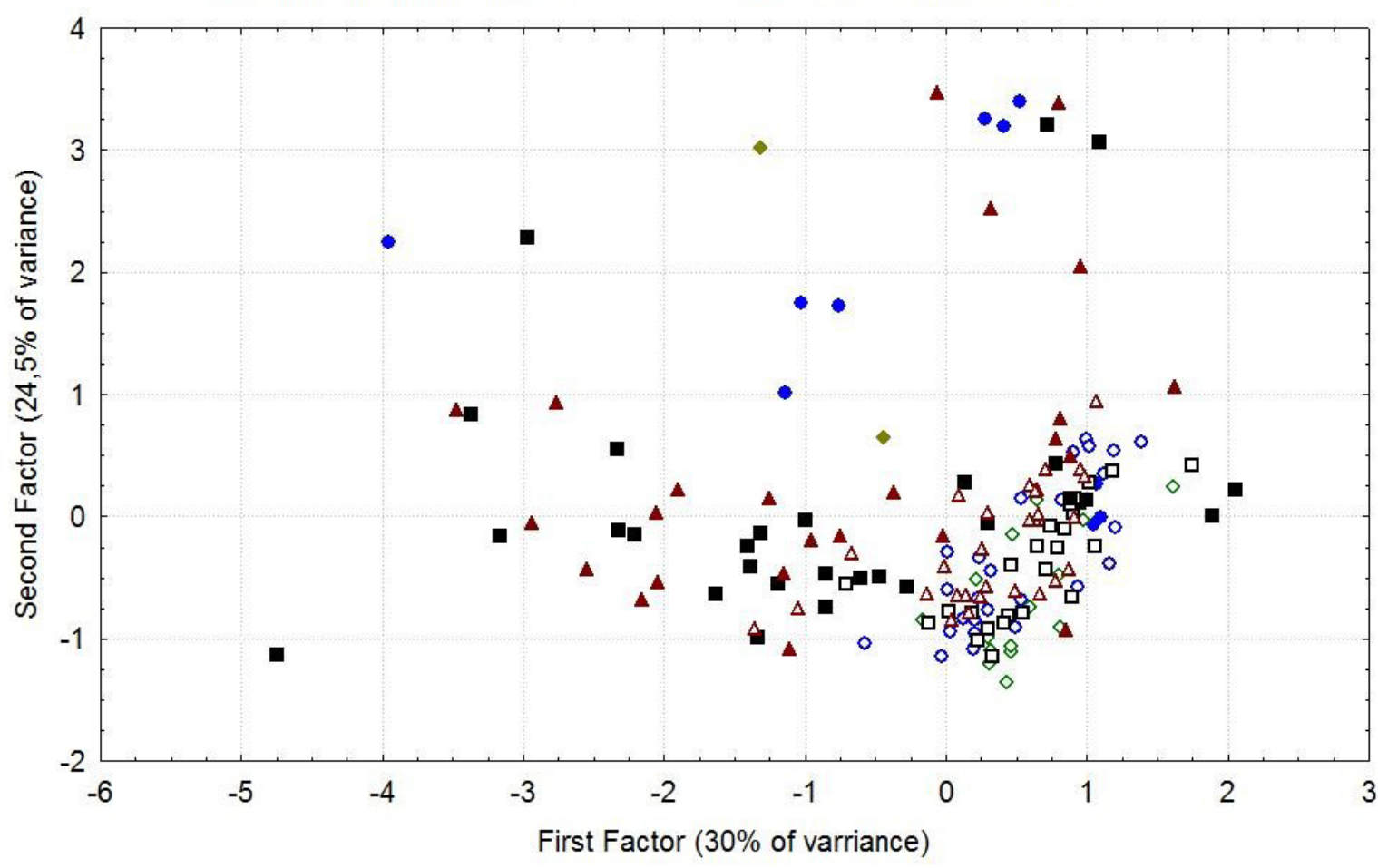

Figure 15. Analysis of principal components for all data segregated by locality and sampling period. The data were signaled by period sampled - Period 1 mesotrophic (2001 to 2005) and period 2 eutrophic (2007 and 2015) - and by lagoon sectors (N, CN, C, S).

Table 4. Correlation of the specific mass of water and the concentrations of nutrients, nitrogenates (DIN) and phosphatics (DIP), of dissolved oxygen and phytoplankton biomass with components 1 and 2 of the PCA.

\begin{tabular}{lcc}
\hline \multicolumn{1}{c}{ Variables } & Component $\mathbf{~}$ & Component 2 \\
\hline NH/DIN & 0.496 & -0.367 \\
DIN & 0.306 & 0.556 \\
DIP & 0.421 & 0.051 \\
Chlorophyll- a & 0.363 & 0.519 \\
DO & -0.423 & -0.054 \\
Specific Mass & 0.416 & -0.531 \\
\hline
\end{tabular}

\section{POPULATION GROWTH IN THE HYDROGRAPHIC BASIN}

It has been proved that the growth of urban areas associated with the ineffectiveness of sewage treatment system can accentuate and speed up eutrophication processes (COELHO; GAMITO; PÉREZ-RUZAFA, 2007). According to the population study by Campanario (2007), population growth at Lagoa da Conceição was on average $6.3 \%$ a year during the period from 2001 to 2015. Considering this value and the estimated population in 2000 for the hydrographic basin of Lagoa da Conceição as 27,432, based on IBGE data (FONSECA, 2006), it is found that the change in the trophic state of the system in 2007 occurred when the population reached approximately 42 thousand. The population growth in the basin is four times greater than the mean rate of population growth in the state of Santa Catarina, which is $1.5 \%$ a year (IBGE, 2010). Estimates performed for the Municipality of Florianopolis indicate a continuous growth of urbanization at rates of $11 \%$ a year until 2020, stabilizing only in 2050 (CAMPANARIO, 2007). Moreover, according to the Integrated Municipal Plan for Basic Sanitation (PMISB-Plano Municipal Integrado de Sanemento Básico), the fraction of the population served by the sanitary sewerage system is only $15 \%$ for the hydrographic basin of Lagoa da Conceição (MPB ENGENHARIA, 2008). Planning and control of this urban growth, both in areas where the basin is used, and in population density are a very important factor in containing and preserving the lagoon and the services offered by this ecosystem, such as maintaining biodiversity, fishing and leisure activities.

\section{CONCLUSION}

The results of the present study point to a major change in the trophic state of Lagoa da Conceição in the last 15 years. The trophic state index (TRIX) enabled the detection of changes from oligo-mesotrophism to eutrophism, beginning in 2007. The smaller concentrations of dissolved oxygen segregated the bottom samples of the Central region of the lagoon from the others, evidencing the effect of physical stratification of the water column in isolating this bottom water. The rapid process of 
anthropic eutrophication significantly influenced the ecosystem metabolism, and became heterotrophic in the Central and South regions. The increase in reduced forms of nitrogen shows the lack of capacity of Lagoa da Conceição to process the changes in the biogeochemical cycle of nitrogen imprinted by urban advance. Among the lagoon sectors most affected by the high loads of nutrients discharged are subsystem S1 (South region) which presented an eutrophic and hyper eutrophic state, and subsystem C2 (Central region) which presented hypoxia and anoxia in the bottom waters. The results obtained show the need to implement continuous monitoring plans that will allow accompanying the biogeochemical dynamics in Lagoa da Conceição, providing further information for impact control and mitigation.

\section{REFERENCES}

ACQUAVITA, A.; ALEFFI, I. F.; BENCI, C.; BETTOOSO, N.; CREVATIN, E.; MILANI, L.; MATTASSI, G. Annual characterization of the nutrients and trophic state in a Mediterranean coastal lagoon: the Marano and Grado Lagoon (northern Adriatic Sea). Regional Studies in Marine Science, v. 2, p. 132-144, 2015.

AEROCONSULT. Relatório final da batimetria do distrito administrativo da Lagoa da Conceiçao e Barra da Lagoa. Florianópolis, 2000.

ANDERSON, M. J.; GORLEY, R. N.; CLARKE, K. R. PERMANOVA+ for PRIMER: guide to software and statistical methods. 2008. 214 p.

ANDRADE, R. C. Estudo da circulação bidrodinâmica da Lagoa da Conceição - SC. 2001. Dissertação (Mestrado em Ciências em Engenharia Oceânica) - Universidade Federal do Rio de Janeiro, Rio de Janeiro, 2001.

BIANCHI, T. Biogeochemistry of estuaries. New York: Oxford University Press, 2006.

BIER, F. Caracteriz̧ação morfométrica e bidrológica da bacia bidrográfica da Lagoa da Conceição, Florianópolis - SC. 2013. 115 f. Trabalho de Conclusão de Curso (Graduação em Engenharia Ambiental) - Universidade Federal de Santa Catarina, Florianópolis, 2013.

BORGO, D.; CATTANI, A. P.; RIBEIRO, G. C.; PICHLER, H. A.; HOSTIM-SILVA, M.; CLEZAR, L.; SPACH, H. L. Os padrões de distribuição dos peixes de uma laguna costeira aberta no Atlântico oeste subtropical são influenciados pelas variações espaciais e sazonais? Biotemas, v. 28, n. 3, p. 93-105, 2015. http:// dx.doi.org/10.5007/2175-7925.2015v28n3p93.

BRANCO, J.; VERANI, J. Dinâmica da alimentação natural de Callinectes danae Smith (Decapoda, Portunidae) na Lagoa da Conceição, Florianópolis, Santa Catarina, Brasil. Revista Brasileira de Zoologia, v. 14, n. 4, p. 1003-1018, 1997. http:/ /dx.doi. org/10.1590/S0101-81751997000400014.

BRANDINI, F. P.; FERNANDES, L. F. Microalgae of the continental shelf off Paraná State, southeastern Brazil : a review of studies The Paraná littoral and plane region. Revista Brasileira de Oceanografia, v. 44, n. 1, p. 69-80, 1996. http://dx.doi. org/10.1590/S1413-77391996000100008.

BRICKER, S.; CLEMENT, C.; PIRHALLA, D.; ORLANDO, S. National estuarine eutrophication assessment: effects of nutrient enrichment in the nation's estuaries. Silver Spring: NOAA, 1999.

CAMPANARIO, P. Florianópolis: dinâmica demográfica e projeção da população por sexo, grupos etários, distritos e bairros (1950-2050). Florianópolis: IPUF, 2007.

CAÑEDO-ARGÜELLES, M.; RIERADEVALL, M.; FARRÉSCORELL, R.; NEWTON, A. Annual characterisation of four Mediterranean coastal lagoons subjected to intense human activity. Estuarine, Coastal and Shelf Science, v. 114, p. 59-69, 2012. http://dx.doi.org/10.1016/j.ecss.2011.07.017.

CLOERN, J. Our evolving conceptual model of the coastal eutrophication problem. Marine Ecology Progress Series, v. 210, p. 223-253, 2001. http://dx.doi.org/10.3354/meps210223.

COELHO, S.; GAMITO, S.; PÉREZ-RUZAFA, A. Trophic state of Foz de Almargem coastal lagoon (Algarve, South Portugal) based on the water quality and the phytoplankton community. Estuarine, Coastal and Shelf Science, v. 71, n. 1, p. 218-231, 2007. http://dx.doi.org/10.1016/j.ecss.2006.07.017.

COSTA, M. F.; BARLETTA, M. Special challenges in the conservation of fishes and aquatic environments of South America. Journal of Fish Biology, v. 89, n. 1, p. 4-11, 2016. PMid:27225985. http://dx.doi.org/10.1111/jfb.12970.

COTOVICZ, L. C. Comparação de modelos e índices para avaliação do estado trófico do Complexo Estuarino-Lagunar Mundaú-Manguaba (AL). Geochimica Brasiliensis, v. 26, n. 1, p. 7-18, 2013.

CURY, V. E. S. Análise espaço temporal do estado trófico de uma laguna costeira subtropical: Lagoa da Conceição, Florianópolis, Santa Catarina. 2016. Dissertação (Mestrado em Engenharia Ambiental) - Universidade Federal de Santa Catarina, Florianópolis, 2016.

DIAZ, R.; ROSENBERG, R. Spreading dead zones and consequences for marine ecosystems. Science, v. 321, n. 5891, p. 926-929, 2008. PMid:18703733. http://dx.doi.org/10.1126/ science. 1156401.

DSIKOWITZKY, L.; FERSE, S.; SCHWARZBAUER, J.; VOGT, T. S.; IRIANTO, H. E. Impacts of megacities on tropical coastal ecosystems: the case of Jakarta, Indonesia. Marine Pollution Bulletin, v. 110, n. 2, p. 621-623, 2016. PMid:27016329. http://dx.doi. org/10.1016/j.marpolbul.2015.11.060.

EKAU, W.; KNOPPERS, B. A. A review and definition of the large marine ecosystems of Brazil. In: HEMPEL, G.; SHERMEN, E. (Eds.). Large Marine Ecosystems of the World: trends in exploitation 
protection and research. The Netherlands: Elsevier Science, 2003. v. 12 , p. 355-374.

FAUST, M.; GULLEDGE, R. Identifying harmful marine dinoflagellates. Contributions from the United States National, v. 42, p. 1-144, 2002.

FERREIRA, J.; WOLFF, W.; SIMAS, T.; BRICKER, S. Does biodiversity of estuarine phytoplankton depend on hydrology? Ecological Modelling, v. 187, n. 4, p. 513-523, 2005. http://dx.doi. org/10.1016/j.ecolmodel.2005.03.013.

FONSECA, A. Efeito da drenagem urbana nas características físico-químicas e biológicas da água superficial na Lagoa da Conceição (Florianópolis, SC, Brasil). Biotemas, v. 19, n. 2, p. 7-16, 2006.

FONSECA, A. Variaça sazonal e espacial das caracteristicas hidroquimicas, dos fluxos de nutrientes e do metabolismo na interface água-sedimento na Lagoa da Conceição. 2004. 180 f. Tese (Doutorado) - Universidade de São Paulo, São Paulo, 2004.

FONSECA, A.; BRAGA, E. S.; EICHLER, B. B. Distribuição espacial dos nutrientes inorgânicos dissolvidos e da biomassa fitoplanctônica no sistema pelágico da Lagoa da Conceição, Santa Catarina, Brasil. Atlântica, v. 24, n. 2, p. 69-83, 2000.

FONTES, M. L. S. Breve estudo espaç-temporal e de impacto do feriado de carnaval e de corpus christi sobre variáveis ambientais nas águas da Lagoa da Conceição - Florianópolis. 2004. Dissertação (Mestrado) - Universidade Federal de Santa Catarina, Florianópolis, 2004.

FONTES, M. L. Dinâmica e composicao das comunidades bacterianas em função da disponibilidade de oxigênio na Lagoa da Conceiçao. 2009. Tese (Doutorado) - Universidade Federal do Rio Grande, Rio Grande, 2009.

FONTES, M.; SUZUKI, M.; COTTRELL, M.; ABREU, P. Primary production in a subtropical stratified coastal lagoon: contribution of anoxygenic phototrophic bacteria. Microbial Ecology, v. 61, n. 1, p. 223-237, 2011. PMid:20809289. http:// dx.doi.org/10.1007/s00248-010-9739-x.

FREITAS DE MAGALHÃES, V.; MORAES SOARES, R.; AZEVEDO, S. M. F. O. Microcystin contamination in fish from the Jacarepaguá Lagoon (Rio de Janeiro, Brazil): ecological implication and human health risk. Toxicon, v. 39, n. 7, p. $1077-$ 1085, 2001.

GASALLA, M. A.; ROSSI-WONGTSCHOWSKI, C. L. D. B. Contribution of ecosystem analysis to investigating the effects of changes in fishing strategies in the South Brazil Bight coastal ecosystem. Ecological Modelling, v. 172, n. 2-4, p. 283-306, 2004. http://dx.doi.org/10.1016/j.ecolmodel.2003.09.012.

GESAMP. Protecting the oceans from land-based activities: land-based sources and activities affecting the quality and uses of the marine, coastal and associated freshwater environment. UNEP, 2001. n. 71,162 p.

GLIBERT, P.; ALLEN, J.; BOUWMAN, A.; BROWN, C.; FLYNN, K. J.; LEWITUS, A. J.; MADDEN, C. J. Modeling of HABs and eutrophication: status, advances, challenges. Journal of Marine Systems, v. 83, n. 3, p. 262-275, 2010. http://dx.doi. org/10.1016/j.jmarsys.2010.05.004.

GLIBERT, P.; SEITZINGER, S.; HEIL, C.; BURKHOLDER, J.; PARROW, M.; CODISPOTI, L.; KELLY, V. The Role of Eutrophication in the Global Proliferation of Harmful Algal Blooms. Oceanography (Washington, D.C.), v. 18, n. 2, p. 198-209, 2005. http://dx.doi.org/10.5670/oceanog.2005.54.

GODOY, F. Modelagem hidrológico-bidrodinâmica da Lagoa da ConceiçãoSC. 2009. Dissertação (Mestrado em Engenharia Ambiental) - Universidade Federal de Santa Catarina, Florianópolis, 2009.

GÓMEZ, R. C. C.; GÓMEZ, M. A. M.; BULGAKOV, S. N. Efectos de los vórtices en sistemas acuáticos y su relación con la química, biología y geología. Interciencia: Revista de ciencia y tecnología de América, v. 33, n. 10, p. 741-746, 2008.

GRASSHOLF, K.; KREMLING, K.; EHRHARDT, M. Methods of seawater analysis. 3rd ed. Grassholf: Wiley-VCH, 1999. 599 p.

HALPERN, B. S.; FRAZIER, M.; POTAPENKO, J.; CASEY, K. S.; KOENIG, K.; LONGO, C.; WALBRIDGE, S. Spatial and temporal changes in cumulative human impacts on the world's ocean. Nature Communications, v. 6, p. 1-7, 2015.

HALPERN, B. S.; WALBRIDGE, S.; SELKOE, K. A.; KAPPEL, C. V.; MICHELI, F.; D'AGROSA, C.; WATSON, R. A global map of human impact on marine ecosystems. Science, v. 319, n. 5865, p. 948-952, 2008. PMid:18276889. http://dx.doi.org/10.1126/ science. 1149345.

HEILEMAN, S.; GASALLA, M. South Brazil Shelf LME. The UNEP large Marine ecosystems report. a perspective on changing conditions in LMEs of the world's regional seas. 2nd ed. Nairobi: United Nations Environmental Program, 2004. p. 235-242.

IBGE - INSTITUTO BRASILEIRO DE GEOGRAFIA E ESTATÍSTICA. Censo: características gerais da população, religião e pessoas com deficiência. Rio de Janeiro: IBGE, 2010.

KJERFVE, B. Coastal lagoons. New York: Elsevier, 1994.

KJERFVE, B.; MAGILL, K. Geographic and hydrodynamic characteristics of shallow coastal lagoons. Marine Geology, v. 88, n. 3, p. 187-199, 1989. http://dx.doi.org/10.1016/00253227(89)90097-2.

KNOPPERS, B.; KJERFVE, B. Coastal Lagoons of Southeastern Brazil: physical and biogeochemical characteristics. In: Estuaries of South America. Heidelberg: Springer, 1999. p. 35-66. 
LANA, P. C.; BIANCHINI, A.; OLIVEIRA RIBEIRO, C. A.; NIENCHESKI, L. F. H.; FILLMANN, G. S. C. S. G.; SANTOS, C. S. G. Avaliação ambiental de estuários brasileiros: diretrizes metodológicas. Rio de Janeiro: Museu Nacional, 2006. 156 p.

LEDO, S.-S. Ecossistemas de Marismas da Lagoa da Conceição III: a produção primaria. In: LEDO S. B.; SORIANO-SIERRA, E. J. (Orgs.). O ecossistema da Lagoa da Conceição. Florianópolis: UFSC, 1999. p. 343-357.

LOTZE, H. K.; LENIHAN, H. S.; BOURQUE, B. J.; BRADBURY, R. H.; COOKE, R. G.; KAY, M. C.; JACKSON, J. B. C. Depletion, degradation, and recovery potential of estuaries and coastal seas. Science, v. 312, n. 5781, p. 1806-1809, 2006. PMid:16794081. http://dx.doi.org/10.1126/science.1128035.

MCDOUGALL, T.; FEISTEL, R.; MILLERO, F. The International Thermodynamic Equation of Seawater (TEOS-10): calculation and use of thermodynamic properties. Global Ship-Based, v. 14, 2010.

MIRANDA, L.; CASTRO, B.; KJERFVE, B. Princípios de Oceanografia Física de estuários. São Paulo: EDUSP, 2002. v. 42, 414 p.

MPB ENGENHARIA. Plano Municipal Integrado de saneamento básico do Município de Florianópolis. Florianópolis: IPUF, 2008.

NIXON, S. Coastal marine eutrophication: a definition, social causes, and future concerns. Ophelia, v. 41, n. 1, p. 199-219, 1995. http://dx.doi.org/10.1080/00785236.1995.10422044.

ODRESKI, L. Influência bidrológica nos processos bidrodinâmicos da Lagoa da Conceição-Florianópolis-SC. 2012. 148 f. Dissertação (Mestrado Engenharia Ambiental) - Universidade Federal de Santa Catarina, Florianóplis, 2012.

PENNA, N.; CAPELLACCI, S.; RICCI, F. The influence of the Po River discharge on phytoplankton bloom dynamics along the coastline of Pesaro (Italy) in the Adriatic Sea. Marine Pollution Bulletin, v. 48, n. 3, p. 321-326, 2004. PMid:14972584. http:// dx.doi.org/10.1016/j.marpolbul.2003.08.007.

RABALAIS, N.; DIAZ, R.; LEVIN, L.; TURNER, R.; GILBERT, D.; ZHANG, J. Dynamics and distribution of natural and humancaused hypoxia. Biogeociences, v. 7, n. 2, p. 585-619, 2010. http:/ / dx.doi.org/10.5194/bg-7-585-2010.

RABALAIS, N.; TURNER, R.; DIAZ, R. J.; JUSTIC, D. Global change and eutrophication of coastal waters. ICES Journal of Marine Science, v. 66, n. 7, p. 1528-1537, 2009. http://dx.doi. org/10.1093/icesjms/fsp047.

RIBEIRO, G. C.; CLEZAR, L.; HOSTIM-SILVA, M. Comunidade Ictíica, sua variacao espacial e sazonal na Lagoa da Conceicao e área adjacente, Ilha de Santa Catarina, SC, Brail. In: SIERRA DE LEDO, B.; SORIANO-SIERRA, E. J. (Eds.). O Ecosistema da Lagoa da Conceição. Florianópolis: NEMAR/CCB/UFSC, 1999. p. 261-273.
ROCHA, C. B. M. Implementação e uso do modelo Mike 21 na análise de cenários hidrodinâmicos na Lagoa da Conceição - SC. 2007. Dissertação (Mestrado em Engenharia Ambiental) - Universidade Federal de Santa Catarina, Florianópolis, 2007.

RODRIGUES, A. S.; KNIESS, C.; RIGOTTI, J. A.; FONSECA, A. Aplicação do modelo TRIX para avaliação da qualidade da água dos rios que drenam para Estação Ecólogica de Carijós, Florianópolis, SC, Brasil. In: SIMPÓSIO BRASILEIRO DE RECURSOS HÍDRICOS, 20., 2016, Florianópolis. Florianópolis: ARBRH, 2016.

RODRIGUES, R. R.; LORENZZETTTI, J. A. A numerical study of the effects of bottom topography and coastline geometry on the Southeast Brazilian coastal upwelling. Continental Shelf Research, v. 21, n. 4, p. 371-394, 2001. http://dx.doi.org/10.1016/ S0278-4343(00)00094-7.

ROVERSI, F.; ROSMAN, P. C. C.; HARARI, J.; ROVERSI, F. Análise da renovação das águas do Sistema Estuarino de Santos usando modelagem computacional. Ambiente e Água: An Interdisciplinary Journal of Applied Science, v. 11, n. 3, p. 566, 2016. http://dx.doi.org/10.4136/ambi-agua.1770.

SANTORO, A.; RICCI, R.; ENRICH-PRAST, A. Lagoa rodrigo de freitas: passado e presente. Oecologia Australis, v. 16, n. 3, p. 334-338, 2012. http://dx.doi.org/10.4257/oeco.2012.1603.02.

SILVA, J. Análise numérica da influência dos aportes fluviais e antrópicos sobre a hidrodinâmica residual e a qualidade da água da Lagoa da Conceição-Florianópolis-SC. 2013. 152 f. Dissertação (Mestrado em Engenharia Ambiental) - Universidade Federal de Santa Catarina, Florianópolis, 2013.

SMITH, S. V.; DUPRA, J. I.; MARSCHALL, C.; CROSSLAND, C. J. Estuarine systems of the South American region: carbon, nitrogen and phosphorus fluxes. Netherlands: LOICZ Reports and Studies, 2000. v. 15.

STRICKLAND, J. D. H.; PARSON, T. A pratical bandbook of seawater analysis. Ottawa: Fisheries Research Board of Canada, 1972. 172 p. Bulletin, 122.

TUNDISI, J. Água no século XXI: enfrentando a escassez. São Carlos: Rima, 2003. 248 p.

VOLLENWEIDER, R.; GIOVANARDI, F.; MONTANARI, G.; RINALDI, A. Characterization of the trophic conditions of marine coastal waters, with special reference to the NW Adriatic Sea: proposal for a trophic scale, turbidity and genralized water quality index. Environmetrics, v. 9, n. 3, p. 329-357, 1998. http:// dx.doi.org/10.1002/(SICI)1099-095X(199805/06)9:3<329::AIDENV308>3.0.CO;2-9.

WETZ, M. S.; HAYES, K. C.; FISHER, K. V. B.; PRICE, L.; STERBA-BOATWRIGHT, B. Water quality dynamics in an urbanizing subtropical estuary (Oso Bay, Texas). Marine Pollution 
Bulletin, v. 104, n. 1-2, p. 44-53, 2016. PMid:26876558. http:// dx.doi.org/10.1016/j.marpolbul.2016.02.013.

WITEK, B.; PLINSKI, M. The first recorded bloom of Prorocentrum minimum (Pavillard) Schiller in the coastal zone of the Gulf of Gdańsk. Oceanologia, v. 42, n. 1, p. 29-36, 2000.

\section{Authors contributions}

Victor Eduardo Cury Silva: He led the research group, wrote the summary of historical information needed to characterize Lagoa da Conceiçao in terms of trophic levels and anthropic impact, in terms data, statistical methods for analysis and discussion of the results obtained, and comparison with data found in the literature regarding other lagoons.
Davide Franco: Collaborating in seeking the statistical method to analyze the data (PCA), to look for the Trophic State Index (TRIX).

Alessandra Larissa Fonseca: Collaborated in looking for historical data, in the presentation and discussion of the results, and in the generation of MDS.

Maria Luiza Fontes: Collaborated in seeking for historical data and in discussing the results.

Alejandro Rodolfo Donnangelo: He collaborated in the discussion of statistical methods and results, seeking information and complementary data. He collaborated with the scientific writing of the article and with the elaboration of figures and maps. 